\title{
"BOUND HAND AND FOOT": RAILWAY WORKERS \\ AND THE 1923 STRIKE IN JAVA*
}

John Ingleson

The railway strike which broke out in Java on May 9, 1923, was the largest and most widespread strike in colonial Indonesia. Called by the Union of Rail and Tramway Workers (VSTP), one of the oldest unions in the colony, it expressed the deepseated discontent among these workers, that had for years been largely ignored by companies and government alike. Thus, although many of the central leaders of the VSTP were also prominent in the Indies Communist Party (PKI), the 1923 strike was not simply a product of PKI involvement in and manipulation of the VSTP, as alleged by the colonial government and the railway companies.

In the following analysis the strike is viewed principally from the perspective of the workers' changing experience, perceptions, and aspirations.

\section{Development of the VSTP}

The VSTP was formed in Semarang, Central Java, on November $14,1908^{1}$ by sixty-three European employees of the three Semarang-based private railway companies, the Netherlands-Indies Railway Company (NIS), ${ }^{2}$ the Semarang-Joana Steamtram Company (SJS), and the Semarang-Cirebon Steamtram Company (SCS). The latter two companies were members of a holding company, known as the Sister Societies, which operated one of the two major privately owned networks in the colony. ${ }^{3}$ The other was operated by the NIS. In forming the VSTP these European workers were following the example of their counterparts in the State Railways, 4 who had established a Staatsspoor Bond (Government Railway Union) in 1905,

* I am grateful to the Australian Research Grants Committee for financial assistance for the research on which this article is based.

1. Locomotief, November 16, 1908.

2. The privately owned NIS (Nederlandsch-Indische Spoorweg Maatschappij) was the largest railway network in Central Java. With its headquarters in Semarang, its major lines ran south to Yogyakarta and Solo and east to Surabaya.

3. The Sister Societies had a total of four operating companies. In addition to the SJS (Semarang-Joana Maatschappij Stoomtram) and the SCS (Semarang Cheribon Stoomtram Maatschappij), there were the Oost-Java Stoomtram Maatschappij (OJO) and the Seradjoedal Stoomtram Maatschappij (SSM). There were a number of small single-line rail and tramway companies operating largely in East Java and tramway companies operating networks in the major Javanese cities.

4. The government-owned State Railways was the biggest of the three major railway and tramway networks in colonial Java. Its largest network was in East Java, centered on Surabaya, but it had an expanding system in West Java, centered on Bandung. 
which claimed a membership of one third of the European State Railways' employees by 1908. The Staatsspoor Bond was predominantly a European union, admitting only top-level Indonesian workers and then without voting rights. ${ }^{5}$ Until 1914 , Europeans also formed a majority in the VSTP and monopolized positions on the central and branch executives. Indonesians were admitted as members, with full voting rights, but no effort was made to recruit large numbers of lower-level workers.

One of the major issues confronting the VSTP in these early years was whether to remain a small, predominantly European, body or to develop into a mass-based union representing the interests of all railway and tramway workers, irrespective of race or status. In those other areas of employment in the colony where Europeans had established unions, they had generally done so on a racially exclusive basis, although some admitted Dutch-speaking Indonesian administrative workers as associate members. Excluded from the European unions but realizing the benefits to be gained from common action, Indonesians began to form their own unions in the $1910 \mathrm{~s}$. The first to do so were clerical and administrative workers employed by the colonial government, but by the late 1910s workers in private industries were also beginning to unionize.

Some European leaders of the VSTP were prepared to permit Indonesians continued membership provided they remained in passive roles, but others advocated their total exclusion. This division in part reflected the wider debate going on among Europeans in the Indies, many of whom were feeling increasingly threatened by the emergence of nationalist organizations. In 1913, Den Hollander, the chairman of the VSTP Central Executive, had publicly argued that the newly formed Islamic nationalist association, Sarekat Islam, should form trade unions for natives, leaving the VSTP as a union only for European workers. ${ }^{6}$ That Den Hollander and others who shared his views found themselves in a minority was largely due to the influence of a prominent Dutch socialist, Henk Sneevliet. Sneevliet became involved in the VSTP in 1913, shortly after arriving in the colony from The Netherlands and at the height of the debate on the VSTP's future. He forcefully argued that trade unions in a colony should be no different from those in Europe: their role was to defend workers' interests against capitalists and the capitalist-controlled government. He urged not only that trade unions in the Indies be multiracial but also that they work mainly on behalf of the lower-paid Indonesian majority. ${ }^{7}$

In October 1913 the VSTP Central Executive, swayed by Sneevliet's arguments, decided to recruit Indonesian members actively and also to give them a role in the union's leadership. The VSTP General Meeting in February 1914 agreed to reserve three out of the seven Central Executive positions for natives. ${ }^{8}$ This marked the

5. H. Sneevliet, Tien Jaren VSTP [Ten Years of the VSTP] (Semarang: n.p., 1919), p. 1.

6. Ibid., p. 6.

7. For discussion of Sneevliet's involvement in labor unions and politics, see: Ruth T. McVey, The Rise of Indonesian Communism (Ithaca: Cornell University Press, 1965), especially pp. 12-14, and Max Perthus, Henk Sneevliet: revolutionair-socialist in Europa en Azie [Henk Sneevliet: Revolutionary Socialist in Europe and Asia] (Nijmegen: Socialistiese Uitgeverij, 1976), especially pp. 89-97. See also D. M. G. Koch, Batig Slot. Figuren uit het oude Indie [Surplus. Figures from the Old Indies ] (Amsterdam: Djambatan, 1960), pp. 110-18 for a portrait of Sneevliet by one of his contemporaries.

8. Volharding, July $30,1914$. 
end of the first stage of the VSTP's growth and the beginning of its transformation into an Indonesian-controlled union. At the end of 1913 the VSTP had only 1,242 members ( 673 Europeans and 569 Indonesians), but by January 1915 it had 2,292 members, with a clear majority $(1,439)$ being Indonesians. ${ }^{9}$ Despite its having begun as a union for employees of the Semarang-based private railway companies, the VSTP's expansion after 1914 owed much to recruitment of workers in the State Railways. By 1918, more than half of its members were State Railways employees, and, although there are no precise figures for later years, it seems that this percentage increased even further by 1923 .

The decision to recruit Indonesian workers and give them a voice in the Executive was not acceptable to all European members, many of whom left the union over the next few years. The exodus increased after 1917, when the VSTP became more assertive and threatened to use its industrial muscle against the railway companies. By 1920, out of a total VSTP membership of 6,494, there were only 236 Europeans, most of whom were lower-level employees who presumably felt that the VSTP would serve their interests better than the European railway unions, which spoke mainly for high-level personnel. ${ }^{10}$

In 1915, as part of the new policy, the VSTP began publishing Si Tetap, a Malay language edition of its existing journal. Its editor was Muhamad Jusuf, a clerk in the Semarang Tramway Company and one of the founding members of the Semarang branch of Sarekat Islam. When Indonesians were first elected to the Central Executive that same year, Jusuf was elected along with three others, including a 16-yearold former State Railways clerk called Semaun. Himself the son of a railway worker, Semaun had come under Sneevliet's influence during the latter's few brief months in Surabaya in 1913, remaining in contact with him after Sneevliet moved to Semarang. A member of the Surabaya branch of Sarekat Islam and literate in both Malay and Dutch, Semaun apparently joined the VSTP's Surabaya branch in the latter half of 1914, and was elected to the branch executive early in 1915. On July 1 , 1916, he gave up his State Railways job and moved to Semarang to become a fulltime salaried VSTP propagandist and editor of Si Tetap. ${ }^{11}$

Semaun's appointment ushered in a period of rapid growth for the VSTP. By 1920 it had established ninety-three branches throughout Java, with a few smaller branches on the west coast of Sumatra and on the Deli plantation lines. The largest branches were at the termini of two or more private railway networks--Cirebon, Semarang and Yogyakarta--and at the State Railways junctions of Surabaya and Madiun, with a much smaller presence in the western region of the State Railways network centered on Batavia and Bandung. ${ }^{12}$ Although they made occasional propaganda tours into West Java, VSTP central leaders concentrated on building up union membership in Central and East Java and never succeeded in gaining more than a small fraction of the railway and tramway workers of West Java. Not that the VSTP's overall membership figures were ever very large, for, at its peak in May 1923 , its 13,000 members represented little more than a quarter of the total Indonesian workforce in the rail and tramway industry in Java. ${ }^{13}$ The membership profile

9. Sneevliet, Tien Jaren VSTP, p. 2 .

10. Volharding, February 10, 1920.

11. Ibid., April 22, 1915 and July 5, 1916.

12. Ibid., February 10, 1920.

13. Si Tetap, February-March 1926. The larger branches in the major cities of East and Central Java recruited higher percentages, with an estimated 50 percent 
seems to have reflected all employment categories--from skilled artisans to unskilled day laborers--though Indonesian administrative and supervisory personnel joined it only in small numbers. ${ }^{14}$ Better educated and originating from higher social strata than most railway workers, some of these upper-level personnel joined the European railway unions as associate members while others remained aloof from unions altogether.

Membership figures are, of course, only one measure of a union's power and cohesion. In some years as little as 60 percent of those recorded as members paid their dues regularly and even in better years the figure was not much more than 80 percent. ${ }^{15}$ On the other hand, many workers who did not join the union, whether from fear of reprisals or skepticism as to the immediate benefits, were nevertheless influenced by its propaganda. Thousands of nonunion railway workers signed petitions drawn up by the VSTP in the late 1910s, and reports on local strikes then and in the early 1920s make it clear that nonmembers as well as members took part.

Apart from its inability to recruit extensively in West Java, the VSTP had great difficulty in organizing workers in the many small private railway and tramway companies linking inland sugar mills to Surabaya, Probolinggo, Pasuruan, and other coastal towns in East Java. Wages and working conditions were generally worse in these enterprises than in the larger private networks of the State Railways. Most had few formal conditions of employment and relied on managers to pay whatever wages they could get away with in their areas. Although hours of work were longer than elsewhere, wages lower, and legal protection nonexistent, at the same time strong dependency bonds existed between managers, foremen, and workers which were more difficult to sustain in the larger companies. This was a major obstacle to VSTP recruitment, linked as it was to workers' fears of retaliation if they joined the union. The companies fostered these fears and seem to have encouraged foremen and supervisors to warn workers of the consequences of joining the VSTP. ${ }^{16}$

The formal structure of the VSTP, like that of almost all unions in the Indies at the time, was designed to maintain central control over the branches. The Central Executive consisted of a chairman, secretary, and treasurer, resident in Semarang, and representatives from all over Java. Owing to the expense of bringing the full Executive together more than two or three times a year, the day-to-day management of the union was in the hands of a Daily Executive composed solely of Semarang residents. The chairman and secretary were salaried officials from the start; after 1914 , so were a number of traveling propagandists and union organizers. (There was a small office staff at VSTP headquarters in Semarang which prepared the industrial submissions of the union and supervised the activities of the branches.)

In practice, however, the Central Executive of the VSTP, like that of other unions, often had difficulty in controlling branch leaders, many of whom were powerful local union and political figures, with personal followings and political links independent of the Semarang leadership. Even local leaders did not have as much control over workers as they might have wished, and most of the short-lived strikes

of State Railways workers in Surabaya belonging to the VSTP on the eve of the strike in May 1923. Resident of Surabaya to Governor-General, May 10, 1923, V 17 December 1923 - O18. (This is a distinguishing number of a file in the Archives of the former Ministry of Colonies, The Hague.)

14. Sneevliet, Tien Jaren VSTP, p. 7.

15. Volharding, July 7, 1915.

16. Ibid., December 22, 1915 and January 20, 1917. 
that broke out repeatedly in the late 1910 s and early 1920 s were spontaneous walkouts caused by local social and economic grievances linked to the general economic conditions in the colony. Local leaders as well as "national" leaders had then to scurry to try to bring the outbreaks under their control.

Increasingly after 1914 VSTP branch leaders were young men, in their twenties in the main, usually employed as clerks, station officials, or conductors, and literate at least in Malay and often in Dutch as well. Literacy and numeracy were, of course, essential for officeholders if minutes were to be taken, correspondence with members and the central executive maintained, and account books kept. The VSTP made a special effort to recruit skilled, literate, or highly placed workers, such as foremen or station-masters, because it realized that these people often had considerable informal power in the workshops, stations, or work-gangs, and that, if they could be persuaded to join, they would bring many others in with them.

For many, a position on the local executive of the VSTP, or indeed of one of the other unions, was their first experience of a modern organization, and later led to their involvement in nationalist activities. Not all branch executive members were, however, railway workers. Some were what might be called professional union organizers, the most prominent of whom in the VSTP was Djaid, chairman of the Cirebon branch after 1918. ${ }^{17}$ Others, like Semaun himself, were ex-railway workers now employed full-time by the VSTP and other unions or by political organizations. Part of the railway companies' response to VSTP industrial action in the 1920 s was to dismiss those viewed as ringleaders. Consequently, more and more VSTP branches came to be led by former railway workers, sustained by small salaries from the union.

The VSTP's growth after 1914 reflected the rapid social and economic changes taking place in Javanese towns and cities. Many members of the expanding urban wage-labor force were gradually becoming aware of the exploitative conditions under which they worked and lived, and were beginning to believe that they might be able to do something about it. An increasing race and group consciousness among urban workers was nowhere more evident than among railway workers. Their occupational mobility, relatively high literacy, residence in distinct railway kampung in the urban areas, and close working proximity with Europeans, all helped heighten this consciousness. In addition, in the early 1900 s Indonesian workers were increasingly assigned to jobs previously the preserve of Europeans, a process which accelerated during the First World War owing to the difficulty of bringing young Dutchmen out to the colony. In the late nineteenth century engine-drivers, stationmasters, and administrative personnel, for example, had almost all been Europeans, as had a large number of the train conductors. By 1914, a majority of enginedrivers, station-masters, clerks, and conductors were Indonesians, and Europeans had moved to supervisory positions. By 1918, only the State Railways employed Europeans as engine-drivers and then only on a small scale. Increasing numbers of skilled Indonesian railway workers, the backbone of VSTP branches, were conscious of the racial inequality in the colony and also, influenced by the urban intellectuals in the nationalist political organizations, of its causes. ${ }^{18}$

17. At the time of the strike in the Semarang-Cirebon Railway Company in August 1920 , Djaid was chairman of the Cirebon branch of Sarekat Islam, chairman of the Cirebon branch of the VSTP, chairman of the Harbor Workers' Union in Cirebon, and adviser or officeholder in numerous other local unions. He was described in government reports as being self-employed, presumably making his living from the salaries he received from Sarekat Islam, the VSTP, and other unions.

18. I have discussed this theme at greater length in my article, "Worker Conscious- 
The VSTP was able to recruit growing numbers of railway workers because it was seen to be successful in defending their interests. It made regular surveys of workers' incomes, allowances, working hours, and living conditions, and presented detailed, well-argued cases for improvements to the managements of the two large private railway companies and the State Railways. Pressure from the VSTP forced railway managements to review their wage scales more often than they would otherwise have done, and made them more aware of the needs of their Indonesian workers and more wary of blatantly unjust action. By the late 1910s, the VSTP was the recognized voice of the Indonesian workforce, with railway managements increasingly prepared to discuss industrial matters with it, even though refusing official recognition. The union was seen by its members as a channel for redressing grievances. Workers who felt unjustly treated by foremen or company managers turned to local VSTP leaders for assistance in mediating their cause with the companies. In many cases the union was successful.

Major grievances among railway workers included long hours of work (ten to twelve hours each day was usual), infrequent days off (one day per fortnight was common), and arbitrary fines imposed for all sorts of errors and misdemeanors. (European employers considered an extensive fine system to be the only way of imposing industrial discipline on workers who had so recently left the less-regimented village world.) Another source of discontent was the high-handed treatment meted out by European supervisors. Physical abuse was rare, but even a newly arrived young European quickly learned a battery of abusive words in Javanese or Malay. The scarcity of company-provided housing, the high cost of rented accommodation, and, of course, the inadequate wages, were further major complaints. Increasingly, union meetings and the VSTP journals stressed that the root of all these problems lay in the blatant racial inequalities of colonial society. Again and again, the stimulus behind local-level demands for improved housing, reduced hours of work, or higher wages was the members' awareness that European employees were so much better treated. A key demand of the VSTP after 1914 was for equal pay and conditions for all workers, irrespective of race. The skilled workers were particularly incensed and were quick to express their discontent in the pages of the VSTP's journals.

In addition to these long-standing grievances, railway workers, along with all wage earners in Java, were deeply affected by the high inflation in the colony between 1913 and 1920. In these years the cost of most ordinary consumption articles, including rice, at least doubled. Prices rose steadily from 1913 until the end of the war in 1918, after which there was an explosion. ${ }^{19}$ Wages had never been high in the colony but in the 1910 s those dependent on wages became even more impoverished as their incomes lagged far behind the enormous increases in the cost of living. The inflation fueled the growth of labor unions in Java and resulted in a continuous wave of strikes between 1918 and 1921. Some of these were spontaneous reactions by workers to their deteriorating conditions, while others were organized attempts to win wage raises. Some gains were made, particularly by the VSTP, the Union of Factory Personnel (PFB), and by unions of skilled urban workers who took advantage of the skilled-labor shortage immediately following the war to force concessions from employers. The gains in wages and allowances and the improvements in conditions of work included the introduction of cost-of-living allowances,

ness and Labour Unions in Colonial Java" (submitted for publication).

19. See Verslag van den Economischen Toestand der Inlandsche Bevolking 1924 (Weltevreden, 1926), 1, Appendix 2. 
conceded by the private railway companies in 1917 and by the State Railways in May 1918. ${ }^{2 \gamma}$

Despite these improvements, the escalating cost of living continued to take its toll of railway workers' living standards. ${ }^{21}$ A wildcat strike in the SCS in August 1920, together with walkouts first in the Probolinggo Tram Company and then in the Malang Tram Company, were symptomatic of the discontent among railway workers. ${ }^{22}$ The VSTP Central Executive, led by Semaun and Pieter Bergsma, a prominent Dutch member of the Surabaya-based Indies Social Democratic Association (ISDV), spent much of its time trying to prevent local strikes erupting and, when they did, trying to get workers back to work so that they could negotiate with the employers. The VSTP Annual Congress in December 1920 carried a series of demands on all railway managements, including improvements in wages, reduction in working hours, increased allowances, and improved company housing. ${ }^{23}$ The demands were served on the three major companies in 1921 , together with a strong hint from VSTP leaders that they could not keep workers' discontent under control much longer. Semaun and Bergsma warned "that the workers will resort to spontaneous protests if these demands are not acceded to," and added that the Congress had instructed the Central Executive to consider industrial action if favorable replies were not received by October $1 .{ }^{24}$

The October deadline passed with none of the demands met. Still the VSTP leaders put off direct action, though rumors had abounded since the middle of the year that a general railway strike was imminent. They were conscious of the smallness of the VSTP strike fund, caused by members' failure to pay their dues on time or sometimes at all, and aware also that the organizational weaknesses in the union made it difficult to achieve a coordinated Java-wide strike. ${ }^{25}$ The threat of a major

20. Volharding, November 20, 1917, April 20, 1918, and May 20, 1918.

21. A commission appointed by the government to investigate the possibility of introducing a minimum wage in Java reported in 1920 that, even though available statistics were incomplete and unreliable, it was convinced that "the lowest level of wages now paid to an uneducated worker are in general too small for an hygienically satisfactory minimum level of existence." Verslag van de Arbeidscommissie betreffende de wettelijke vaststelling van minimum-loonen voor werknemers op Java en Madoera [Report of the Labor Commission Concerning the Institution of Legal Minimum Wages for Employees in Java and Madura] (Weltevreden: Landsdrukkerij, $1920)$, p. 11.

22. There is a detailed discussion of the Cirebon strike in Volharding, August 10, 1920. The strike in the Probolinggo Tram Company in April 1920 is reported in Oetoesan Hindia, April 22 and 23, 1920, and Volharding, June 10, 1920. The strike in the Malang Tram Company in July 1920 is reported in Oetoesan Hindia, August 24, 1920, and Volharding, August 10, 1920.

23. The demands adopted by the December Congress are enclosed in VSTP Central Executive to Management Committee NIS, July 12, 1921, NIS Archives, Door 4, Dossier 4. (This is an abbreviation referring to the Archives of the NederlandscheIndische Spoorweg Maatschappij in the General State Archives, The Hague.)

24. VSTP Central Executive to Management Committee NIS, July 12, 1921, NIS Archives, Door 4, Dossier 4.

25. The VSTP Central Executive constantly berated branch executives for failing 
strike if conditions did not improve was probably seen as a more potent weapon than a strike itself. VSTP leaders were fully aware of the abject failure of the Pawnshop Workers' strike in January 1922 and the consequent dismissal of many workers. ${ }^{26}$ But railway workers' discontent showed no sign of abating, maintaining pressure on VSTP leaders to do something to force improvements from railway managements.

\section{Political Organizations and Labor Unions}

The growth of labor unions was but one consequence of the social ferment in Java in the early twentieth century. Another was the emergence of nationalist political associations, ranging from the moderate, Javanese aristocrat-dominated Budi Utomo to the multiracial Insulinde and, after 1912, the Islamic nationalism of Sarekat Islam. ${ }^{27}$ Sarekat Islam tapped not only the growing social malaise in urban and rural Java but also the Islamic revival which had been gaining momentum in Java since the late nineteenth century. Active involvement in labor unions implied a greater awareness of the nature of colonial society and a consciousness not only of the need for change but also of the key role of modern institutions in achieving it. Not surprisingly, then, many of those who provided local as well as "national" leadership in labor unions were also actively involved in Sarekat Islam. Leadership became interlocking and, in the minds of many, the struggle to improve the workers' lot was inseparable from the broader effort to regenerate the society as a whole and free it from colonial oppression.

While many unions had existed before the emergence of Sarekat Islam, by the mid-1920s Sarekat Islam leaders began to create labor unions among hitherto unorganized workers. Most, like the Union of Factory Personnel or the Typographers' Union, were independent organizations, albeit linked to Sarekat Islam through interlocking leaderships. Others, particularly after 1918, were more closely linked to the labor-union section of Sarekat Islam. Involvement in labor unions was seen as an important way of expanding Sarekat Islam membership and influence in the urban areas. While local leaders had considerable freedom of action, "national"level Sarekat Islam leaders endeavored to moderate them and urge caution in confronting employers and government.

Sarekat Islam was not the only political organization involved with the labor unions. The Indies Social Democratic Association (ISDV), founded in Semarang

to extract membership fees on a regular basis. In December 1921 , for example, less than 30 percent of members paid their monthly dues. Volharding, February 1922. Membership contributions in December 1922 amounted to $f 2,831.60$ and in January 1923 to f2,757.08, enough to cover operating costs but not to build up a strike fund. Si Tetap, December 31,1922 and Jan/Feb 1923, IPO, 1923, Pt. 1, No. 8, p. 387 and No. 12, p. 635.

26. For a discussion of the Pawnshop Workers' strike, see McVey, Rise of Indonesian Communism, pp. 120-24, and Akira Nagazumi, "The Pawnshop Strikes of 1922 and the Indonesian Political Parties," Archipel, 8 (1974), pp. 187-206.

27. There is a considerable body of literature on the early critics of colonialism and the emergence of nationalist organizations. See especially: Robert Van Niel; The Emergence of the Modern Indonesian Elite (The Hague: van Hoeve, 1960); Akira Nagazumi, The Dawn of Indonesian Nationalism: The Early Years of Budi Utomo, 1908-1918 (Tokyo: Institute of Developing Economies, 1972); McVey, Rise of Indonesian Communism; Deliar Noer, The Modernist Muslim Movement in Indonesia, 1900-1942 (Kuala Lumpur: Oxford University Press, 1973). 
in 1914 by a small group of Dutch socialists, was increasingly involved in organizing urban workers (and also, to a much smaller extent, rural workers after 1917). ${ }^{28}$ It thus came into direct competition with Sarekat Islam. The result was that the major unions became linked to one or the other political organization on account of their leaders' personal affiliations. With the founding of the Indies Communist Party (PKI) in 1920, the competition with Sarekat Islam became much stronger. Attempts to form a Federation of Trade Unions in 1920 failed because of the increasingly bitter disputes between leaders of the Sarekat Islam and the PKI. When in October 1921 the Sarekat Islam imposed party discipline by forbidding its members to belong also to the PKI, bitterness between the two political parties increased and spilled over into the labor unions. ${ }^{29}$

While the conflict between the Sarekat Islam and the PKI was reflected in their increased competition to attract labor-union affiliates, only rarely did this lead to competitive unions in the same industry. Unions continued to be linked to one or the other political party through their leaders, but the ideological and personal disputes at this level were not reflected in the day-to-day organization of the union. At the grass-roots level, all unions, whether connected to the PKI or Sarekat Islam, responded to the common social and economic grievances of the workers. The unions with PKI leaders were no more militant than those with Sarekat Islam leaders, which were involved in strikes just as frequently, if for no other reason than because most strikes occurred spontaneously rather than as a result of deliberate policy.

The Indies government viewed PKI involvement in labor unions as more dangerous than that of Sarekat Islam, not because of PKI actions as such but because of what the government saw as the PKI's wider political goals. While countering all labor unrest and strikes in the same way, whether they came from the Sarekat Islam-connected PFB and Pawnshop Workers' Union or from the PKI-connected VSTP, the government adopted a generally more uncompromising stance towards unions led by men who were also PKI leaders. As it saw the PKI as an advocate of revolution, the government also viewed all unions in any way connected with it as part of a Communist masterplan. The VSTP was doubly vulnerable, not only because its leaders were prominent PKI members but also because of the crucial importance of the railway system to the Indies export economy.

All union leaders, whether members of the PKI or of Sarekat Islam, were well aware of the political realities of the colonial situation and were careful to keep one eye on the government while trying to use the system as much as possible to force concessions out of employers. Semaun, as chairman of the VSTP after 1918, chairman of the central executive of the PKI from 1920, and adviser to a number of other unions, was essentially cautious in his approach to the labor movement. He was aware of the value of strike action but aware also that in a colonial society it could only be an effective weapon if used sparingly in carefully calculated and controlled situations. He was well read in the history of the European labor movement and aware of the considerable differences between the social and political consciousness of Indonesian workers and that of their European counterparts. In his view, the first tasks of Indonesian unions were to strengthen their internal organization, educate their members to a stronger consciousness and commitment to the union, and cooperate in industry-wide and national labor federations. Semaun clearly saw that a divided labor movement was a weak movement and that, in a country where there was an underdeveloped worker consciousness, a repressive colonial govern-

28. McVey, Rise of Indonesian Communism, pp. 7-34.

29. Ibid., pp. 76-105. 
ment, and a large pool of unemployed from which strike-breakers could easily be drawn, unions had to operate with caution. Convinced that much could be achieved through organizing workers and representing their grievances to companies and government, he was a tireless negotiator at this task. ${ }^{30}$

\section{The VSTP and the Recession}

The limited but hard won gains made by the VSTP in the late 1910s were threatened in mid-1922 by the sudden recession in the Indies economy and the massive cuts in most areas of government expenditure. The railways were a barometer of the economic health of the colony. When the economy boomed, as it did for a few years after 1918, so did freight and passenger loads as well as profits. But when the economy faltered, as in 1922-23 in conjunction with the world-wide recession, there were less of the highly profitable export crops to move and passenger levels also dropped away. Concerned at falling loads and declining profits, in the middle of 1922 the private railway companies announced that they would phase out the cost-of-living allowances in three equal installments, on June 1, 1922, January 1 and March 1, 1923. ${ }^{31}$ The government announced at the same time that the costof-living allowance for all government employees would be removed on January 1 , $1923 .{ }^{32}$

These economies were bad enough, but they were quickly followed by a series of other cost-cutting measures. In October 1922 the NIS, for example, introduced a cash inducement for its workers to resign and announced that annual wage increments due the following January would be halved. On December 28, it raised rentals for company-owned houses from 10 percent to 15 percent of wages and stopped paying housing allowances in lieu of access to company-owned houses. On December 29, starting wages and promotion increments were lowered, and on January 1, 1923 the clothing regulations were changed so that the company would only provide the initial set of clothes and the workers would have to repair and replace these at their own expense. On April 26, all automatic wage increments were frozen and on May 1 overtime allowances were changed to the disadvantage of workers. ${ }^{33}$ Similar or even harsher measures were introduced by the other private railway companies and by the State Railways. In December 1922, they began to dismiss a few workers whom they declared redundant. These dismissals raised fears among the workers that widespread redundancies would soon be declared. ${ }^{34}$

The impact of these measures on the Indonesian workforce was considerable. Apart from the worsening conditions of employment, reduced promotion opportuni-

30. For a discussion of Semaun's general approach to the labor movement, see ibid., especially pp. 124-54. Semaun was a prolific writer, publishing numerous articles in the Dutch- and Indonesian-language press, particularly in Het Vrije Woord, Volharding, and Si Tetap. See also his pamphlet, Penoentoen Kaoem Boeroeh [Workers' Demands] (Semarang: n.p., 1920).

31. Verslag Staking Mei 1923 [Report of the May 1923 Strike] (Verzoeningsraad voor de Spoor- en Tramwegen op Java en Madoera) [Arbitration Board for the Railways and Tramways in Java and Madura], pp. 15-16. Copy in V 5 November 1925 Z15.

32. Ibid.

33. Chairman of the Management Commiteee (Wouter Cool) to Directors, November 14, 1923, NIS Cabinet Archives, Nr 400.

34. Volharding, January 1923. 
ties, and loss of important fringe benefits such as housing allowances, the actual weekly cash incomes were noticeably lower. Among the better-paid skilled workers, such as engine-drivers, conductors, and station-masters, with their rising expectations and patterns of consumption, as well as among the lower paid majority who lived on the margins of existence, the suddenness of the cash cuts aroused the greatest discontent.

Workers in the State Railways were much more immediately affected than those in the private railway companies. The government-appointed inquiry into the causes of the May 1923 strike calculated that when the cost-of-living allowance was halved in the State Railways on January 1, 1923, the wages of lower-paid workers earning $\mathrm{f} 20$ or less per month--the great majority of native workers--dropped by a massive 21 percent. Equivalent groups in the private railways suffered no more than a 13.5 percent drop in wages and in most cases considerably less. ${ }^{35}$ The discrepancy was caused by the way in which the private companies and the State Railways withdrew the cost-of-living allowances. The private companies ended the cost-of-living allowance, but as a temporary measure introduced personal allowances for all permanent employees. For those earning over f50 per month this personal allowance was to equal the last cost-of-living allowance. For those earning less than f50 per month it was to be a flat 10 percent of wages rather than the previous $f 5$ cost-of-living allowance. The personal allowances would be reduced proportionately as workers received annual wage increments or promotion. By these measures, existing employees were cushioned against the loss of the cost-of-living allowance, though any new workers were engaged at base rates. ${ }^{36}$ In the State Railways, however, where basic rates were in any case quite a bit lower than in the private companies, the cost-of-living allowance made up 60 percent of total wages for those earning less than f50 per month. The sudden halving of this, with its foreshadowed abolition on June 1, 1923, had a devastating effect on workers' cash resources. ${ }^{37}$

It is difficult to compare with any accuracy wages and conditions in the three major railway networks, the NIS, the Sister Societies, and the State Railways, because of the different ways total wages were calculated. Most workers received a basic rate according to their job, usually on an incremental scale, supplemented by kilometer money (based on distances traveled by train crews), diligence money (based on regular attendance at work), and overtime payments. However, all reports, including two government-appointed inquiries in 1922 and 1923, agreed that conditions were best in the NIS and worst, by a considerable margin, in the State Railways. An inquiry into labor conditions in the Semarang-Cirebon Railway Company, a member of the Sister Societies, reported in December 1922 that conditions there compared most favorably with those in the State Railways. ${ }^{38}$ It is significant

35. Verslag Staking Mei 1923, pp. 13-14. The government's Officer for General Matters in the Volksraad, Schrieke, stated that at the time of the strike there were 13,123 State Railways native workers earning less than f25 per month. This was more than half of the native workforce. Handelingen der Volksraad [Proceedings of the Volksraad], 1923, First Session, p. 428.

36. Verslag Staking Mei 1923, pp. 13-16; Speech by Soetadi, June 13, 1923, in Handelingen der Volksraad, 1923, First Session, pp. 78-79.

37. Verslag Staking Mei 1923, pp. 13-16.

38. Rapport arbeids voorwaarden SCS [Report on the Labor Conditions in the $\mathrm{SCS}$ ] by J. B. Peyrott, enclosed in Director of Government Industries to GovernorGeneral, December 29, 1922, Secret Mail Report 1923/13 (this is the distinguishing number of a file in the Archives of the former Ministry of Colonies, The Hague). 
that the 1923 strike was considerably more extensive and long-lasting in the State Railways than in the Sister Societies and received only minimal support in the NIS.

After the onset of the recession, central leaders of the VSTP were under even greater pressure from branch executives and ordinary members to take industrial action in defense of workers' living standards. In response to the growing pressure from below, and with an eye to retaining credibility, in June 1922 they began a campaign against the economy measures and the foreshadowed cuts in wages and conditions in the railway industry. Semaun had returned to the Indies from a seven-month visit to the Soviet Union in late May, exhilarated by the experience yet even more aware than before of the effects of the world recession on Indonesian workers. He immediately took over again as VSTP chairman and began to rebuild the union, which had lost over half of its membership since his departure overseas in October 1921. ${ }^{39}$

Semaun's strategy was to organize and channel railway workers' grievances through public meetings and union propaganda, designed in part to prepare them for stronger action if necessary and in part to convince railway managements of the depth of the discontent. He hoped to persuade the government to change its economic policies or at least maintain neutrality in the VSTP's dispute with railway managements by convincing it that the issues were industrial ones. It was essential for the success of this strategy that VSTP central leaders retain careful control over local hotheads and constantly stress at public meetings their intention to use only peaceful and legal means to achieve their ends. He repeatedly argued at union meetings that strike action should be avoided if at all possible, because its impact on workers would be heavy and its result not at all certain. ${ }^{40}$

Meetings were held in towns and cities throughout Java in the latter half of 1922 , protesting the economy measures and mobilizing workers to join the VSTP as their own way of defending living standards. Memorials were despatched to the Governor-General, the Volksraad, and the Lower House of the Netherlands Parliament, and support was sought from unions in The Netherlands. Other unions in the Indies joined the protests against the proposed cuts in government spending and the withdrawal of cost-of-living allowances. Indeed, the recession was the catalyst for a revival of limited cooperation between labor unions, with the formation in December 1922 of the Persatoean Vakbond Hindia (Indies Trade Union Federation--PVH), a federation of eighteen Indonesian unions representing 32,720 members. ${ }^{41}$ The PVH, however, was no more successful in bringing a degree of unity to the labor movement than had been the short-lived federation of $1920 .{ }^{42}$ Dissimilarities in the structures of the various labor unions, the preoccupation of most union leaders with the problems of integrating their own branches, and the personal and ideological differences between leaders at the "national" level, made such a federation premature.

VSTP leaders had further discussions with the managements of the three major railway networks in an effort to make them aware of the groundswell of discontent

39. McVey, Rise of Indonesian Communism, pp. 134-35.

40. See, for example, a speech of Semaun at a VSTP meeting in Semarang on June 14, 1922. A prominent PKI leader present at the meeting, Soeradi, is reported to have criticized Semaun's attitude to industrial action, stating "he has become cool in thought and cool in his heart also." Locomotief, June 15, 1922.

41. Volharding, January 1923.

42. See McVey, Rise of Indonesian Communism, pp. 45, 76-105. 
among their Indonesian workforce. Their letter to the directors of the SemarangJoana Steamtram Society was typical of those sent to all companies. They protested that the abolition by the SJS of cost-of-living allowances would save the company only f50,000 in 1922 and argued that to cut the purchasing power of workers even further would only deepen the malaise, further reducing company profits. They urged the directors to consider the people affected by their decisions:

There are in the Indies, the land of wealth, thousands of unemployed natives. Because of the absence of government measures, these unemployed people would be left to their own fate if it was not for a centuries-old tradition of family support. Their relatives, on whose labor they now live, are themselves mostly simple workers. Whereas before the world crisis the lives of these workers were already hard, even more are they now when, as well as their own families, they also have to support their unemployed relatives. ${ }^{43}$

The revived VSTP activity was reflected in a considerable growth in its membership, from a low point of around 8,000 in June 1922 , to approximately 11,000 at the beginning of March 1923 , and around 13,000 by the beginning of May. ${ }^{44}$ At meetings throughout Java, Semaun, Kadarisman, Sudibio, and others stressed the need for workers to unite behind the union in order to fight the economies. 45 Kadarisman took the battle to Sumatra when, from late November 1922 until early January 1923, he made a propaganda tour, speaking at public meetings and encouraging local branches to expand their membership and extend their consciousness-raising programs. ${ }^{46}$ Reports on branch meetings make it clear that the economy measures and the consequent drop in wages were the major topics agitating ordinary members. Motions were passed condemning the cuts and proposals formulated for discussion

43. VSTP Central Executive to Directors of Semarang-Joana Steamtram Company, November 27, 1922, Sister Societies Common Archives, 091-912II. These papers are located in the General State Archives (The Hague).

44. Attorney-General to Governor-General, March 2, 1923, V 1 October 1923 E14.

45. Kadarisman was born in Pasuruan in 1890. He was educated at a Second Class Native School. From 1907 to 1913 he worked as a clerk with the Semarang Municipal Council and from 1913 to 1915 with the Semarang-Joana Steamtram Society in Semarang. In December 1915 he was dismissed by the SJS and in February $1916 \mathrm{em}-$ ployed by the VSTP as a clerk. From 1917 he was Secretary of the VSTP and a prominent member of the PKI, until his arrest in November 1926, along with thousands of other PKI members. See Official Report of interrogations of PKI suspects in Semarang to Governor-General, December 22, 1926, V 1 July 1927-T10. Sudibio was born in Banyumas in 1881 and at 42 years of age was the oldest Indonesian member of the VSTP Central Executive at the time of the strike in 1923. He worked as a clerk with the NIS in Semarang before resigning in December 1922 to work as a full-time VSTP propagandist and editor of Si Tetap. Kemadjoean Hindia, September 1,1923 , reporting on his trial at the Bandung District Court on August 22, 1923, charged with breaking laws on public speeches just before the outbreak of the May strike.

46. During this tour Kadarisman reportedly told his audiences that, if the costof-living allowance was withdrawn, then VSTP members should only pay the price they considered proper for goods bought in shops. If the shopowner objected then the goods should simply be taken and a "proper" price left behind. AttorneyGeneral to Governor-General, March 2, 1923, V 1 October 1923 - E14. 
at the next Congress, demanding industrial action to improve working conditions in the industry. The call to strike, which had been heard in most VSTP branches and in the columns of Volharding and Si Tetap over the past two years, became by the end of 1922 a resounding demand for action.

All this activity failed to move either the government or railway managements. In November the VSTP Central Executive decided to bring the matter closer to a head by calling a Congress for Semarang on February 3 and 4, 1923. The "Great Congress," as it was labeled in advertising handbills distributed in Semarang late in January, took place in an atmosphere of tension and drama. ${ }^{47}$ For the duration of the two-day Congress, the government placed armed police and military guards at all stations and organized police and military patrols of major railway lines throughout Java, ostensibly because it feared some sort of disturbance or sabotage. In reality it was a calculated show of strength. ${ }^{48}$ Against this background of intimidation Semaun delivered the keynote address on the evening of February 3 to a public meeting attended by over 3,000 people. He spoke long and eloquently in an endeavor at one and the same time to arouse his listeners' active support and to impress upon them the importance of cool heads and careful action. After lamenting that the workers had "gone back to sleep" after the gains of 1920, he rejoiced that they had been aroused from their slumber by the recession, once again realizing that their livelihood could only be safeguarded by active union membership. He cautioned, though, as he had many times before, that the VSTP intended to defend their interests through "proper" and legal means only. ${ }^{49}$

The crucial decisions of the Congress were taken at a closed meeting of branch representatives held in the VSTP offices on the morning of February 4, with 100 representatives from seventy-nine branches in attendance. In accepting the overwhelming vote in favor of a strike as clear evidence that the railway and tramway workers' patience was exhausted, Semaun again warned delegates against actions such as those at earlier strikes in the Malang and Probolinggo tram companies when, after the strikes had failed, a number of trams were deliberately derailed. ${ }^{50} \mathrm{He}$ concluded by expressing the hope that the authorities would take notice of the views of railway workers. If they did not, he asserted, the VSTP Executive would not be responsible for the consequences.

47. See Appendix 1, Attorney-General to Governor-General, March 2, 1923, V 10 October 1923 - E14.

48. Manifesto VSTP, dated April 23, 1923, copy enclosed in Sister Societies Common Archives, 745-I; Sinar Hindia, May 7, 1923, IPO, Pt. 2, No. 19, p. 258.

49. "Report on the public meeting of the VSTP held on the evening of February $3 / 4,1923$ in the Sarekat Islam office at Semarang," enclosed in V 1 October 1923 E14.

The opening ceremony of the Congress only confirmed the government's conviction that the VSTP was a tool of the PKI. After Sudibio's welcoming speech, thirty boys and girls from the local Sarekat Islam school marched to the front of the hall and, after three of them made a short speech in remembrance of Tan Malaka, the PKI leader exiled in March 1922, they sang three songs, "Forward Proletariat," "The Socialist March," and "The Internationale." Sinar Hindia, February 7-14, 1923, IPO, 1923, Pt. 1, No. 7, p. 290, and Volharding, February-March 1923.

50. On the Malang strike see Oetoesan Hindia, August 24, 1920, and Volharding, August 10, 1920. On the Probolinggo strike see Oetoesan Hindia, April 22 and 23, 1920 , and Volharding, June 10, 1920. 


\section{Preparing for a Strike}

Although the Congress had decided to strike if negotiations with the railway managements were fruitless, VSTP central leaders continued to try to persuade the companies to make some concessions in order to ward off pressures from below for a strike. They were still reluctant to launch a strike, which they knew would bring hardship to many workers and the outcome of which was far from certain, if they could possibly achieve their goals through threats and negotiations. Branch meetings in February and March were addressed by Central Executive members, especially by Semaun, Kadarisman, Sugono, Sudibio, and Najoan, and the public campaign was kept up to maximize the pressure on the railway managements. The salaries commission, which had been established by the government to recommend improvements in the wages of government employees, was addressed on February 19, by Semaun and Najoan, who again urged increased wages for the lowest-paid workers in the railways. They were clearly disappointed by the Salaries Commission's decision on February 24 to give lower-paid workers in the railways an increase of between five and ten percent only. ${ }^{51}$

At the beginning of April the VSTP Executive again arranged meetings with the managements of the three major railway networks. Little was achieved beyond vague promises to keep the Indonesian workers' plight in mind if further cuts were necessary. The VSTP's three major demands--reversal of all economy measures, including restoration of cost-of-living allowances, establishment of an eight-hour working day, and creation of an Arbitration Board for the railway industry--were rejected. Semaun concluded the meeting with the Chief Inspector of the State Railways by warning:

Now we will let the workers themselves speak. We have tried to go through the right channels but the workers' lot is becoming increasingly bad and it goes without saying that this will find its own outlet. ${ }^{52}$

It was increasingly clear to VSTP leaders that railway managements were not prepared to make any concessions and were, indeed, preparing to ride out any strike. But still they hesitated to set a definite date for a general strike. It loomed closer on April 23, however, when Semaun sent a signed circular to all branches for distribution to members, calling on them to be prepared for a strike at any time. In this circular Semaun recounted the deteriorating conditions in the railways and tramways and the decision of the February Congress to take direct action if negotiations with the managements did not bring about improvements. The Executive had met the managements of all networks but had received no satisfaction. He then announced the itineraries of the VSTP propagandists, Sudibio, Sutikno, Tjokrosudono, Ngadino, Sugono, Kadarisman, Abdulrachman, Sukirno, Sanusi, and himself, who would visit all branches between May 8 and 25 to explain the current situation. Branches were urged to organize meetings and ensure that as many workers as possible attended. The circular concluded with

51. McVey, Rise of Indonesian Communism, pp. 148-49. In a circular to VSTP members on April 23, Semaun lamented, "Oh, the poverty increases because, while wages are reduced, sugar prices become higher, clothing prices begin to increase, coffee prices become higher and the price of rice also increases." Manifesto VSTP, dated Semarang, April 23, 1923, copy enclosed in Sister Societies Common Archives, 745-II.

52. "Discussion on April 12, 1923 with the Central Executive and a few other representatives of the VSTP," enclosed in Acting Chief Inspector of State Rail and Tramways to Governor-General, April 16, 1923, V 24 August 1923 - 24. 
a statement by Kadarisman that, if the strike broke out, Semaun would immediately assume complete powers over the union until it was concluded. Finally, he reported that on April 19 the Resident of Semarang had threatened Semaun with externment, but to no effect: "Jail or externment is not so bad, because the life of the poor workers is like life in a jail or in exile." 53

The Resident of Semarang's warning to Semaun seems to have finally convinced VSTP leaders that further negotiations with railway managements would achieve nothing. Further, it probably also made them realize that the government would not remain neutral much longer, thereby drastically changing the balance of power in the dispute with railway managements. These twin realizations were probably the reason for Semaun foregoing his normally cautious approach on April 30, when he stated at a public meeting of the PVH that, if he or any other VSTP leader was arrested, the railway strike would break out immediately. ${ }^{54}$ He repeated the threat at a large public meeting organized by the VSTP at Semarang on May 6 , when over 3,000 people heard him recount the abject failure of negotiations and state that there was no other way to achieve their goals than by a general strike. The date of the strike had yet to be determined, but, if he was arrested, then it must begin the following morning--a call which brought thunderous applause from his audience and loud calls of "strike," "strike," "good," "good," and "splendid." 55

VSTP plans called for a large public meeting in Semarang on June 5 at the conclusion of the propagandists' tour of branches in Java, when the timing of the general strike would be further discussed. ${ }^{56}$ To be most effective the strike would have to be held after the sugar milling season was in full swing in July, when the railways operated at full capacity and when shipping schedules, contract dates, and the lack of storage space at the inland processing mills would maximize the chance of forcing concessions from railway managements. Given these plans, it was extremely risky for Semaun to challenge the government openly on April 30 and May 6. Although, in retrospect, it appears to have been a major political error and a strategic blunder, as Ruth McVey has argued, ${ }^{57}$ it was a calculated action rather than simply a result of Semaun losing his temper after the Resident of Semarang's warning twelve days earlier. He may have thought that he could ward off impending

53. VSTP Manifesto, April 23, 1923, copy enclosed in Sister Societies Common Archives, 745-I. The Manifesto argued, in part, that "if you work, you still find yourself in misery and a sorrowful condition; if you do not work, the result is the same. Therefore, railwaymen, being up or down is a lottery."

54. See Governor-General to Minister of Colonies, May 16, 1923, V 14 July 1923 - 15.

55. There are reports of this meeting in Sinar Hindia, May 7, 1923, IPO, 1923, Pt. 1, No. 19, pp. 256-59, and Kemadjoean Hindia, May 11, 1923. Semaun is reported also to have told this meeting: "I have already explained at Surabaya that it is better to begin a general strike, which is carefully controlled, than to carry out sabotage. We know that a general strike is the best way. For whether we strike or not our lives are still miserable, therefore better not to work." Resident of Semarang to Governor-General, May 31, 1923, V 24 August 1924 - 24. At this meeting a number of speakers promised the full support of their organizations if a railway strike broke out. These included Soemantri, from the Semarang branch of Sarekat Islam and the Union of Regional and Municipal Council Workers; Robbers, from the Radical Concentration; Ngadino, from the Postal Workers' Union; and Soeradi, from the Chauffeurs' Union.

56. Kemadjoean Hindia, May 11, 1923.

57. McVey, Rise of Indonesian Communism, p. 150. 
government intervention a little longer by raising its cost. He may also have reasoned that his own arrest could easily be followed by the arrest of other VSTP leaders, thereby decapitating the union before the pressure of a strike could be brought to bear. In these circumstances an immediate strike after the first arrest might be the only way to prevent the destruction of the union.

Semaun's concern about the outcome of a strike was not shared by local leaders, who not only enthusiastically favored strike action but also believed that it would quickly bring the railways to a standstill. Repeatedly, at branch meetings in February and March, local leaders argued along the lines of the Tanahabang (Batavia) representative to the February Congress, who saw a strike as necessary because "one must teach the Managers a lesson." ${ }^{58}$ The chairman of a VSTP meeting at Pungkurweg (Bandung) on March 9 urged members to hold firm to their decision to strike if their demands were not met:

Remember that the will to strike must come from the heart and not be stirred up by others. We must teach the State Railway management a lesson by striking. But the strike must be general and not merely a local one. The way to oppose the economy measures is to strike. Remember that we live in a time of economising and that we must not allow this to continue. Fear not, if we strike our friends will help us. ${ }^{59}$

Even Sudibio, a propagandist and member of the Daily Executive, argued that the railway industry could not hold out longer than a week if a strike occurred. ${ }^{60}$ Many leaders, both local and central, believed significant support would be given them by other unions and there would be sympathy strikes among postal, telephone, pawnshop, and printing workers. ${ }^{61}$ On the trains and the trams, in the stations and railway workshops, a sense of impatient expectation was building up as talk of a strike became commonplace.

\section{The Arrest of Semaun}

The Resident of Semarang's warning to Semaun was the first public sign that the government was contemplating action against him. A month earlier, for the third time in two years, Governor-General Fock and the Council of the Netherlands Indies had discussed the possible internment of both Semaun and Darsono, another prominent PKI leader, in response to a proposal by the colony's Attorney-General, Wolterbeck Muller. ${ }^{62}$ Fock had then decided to wait before finally deciding on the Attorney-General's request. Clearly he was uncertain as to whether to precipitate a strike by ordering the arrests or to wait in the hope that the moderating influence of Semaun would be successful within the VSTP.

58. Sinar Hindia, February 7-14, 1923, IPO, 1923, Pt. 1, No. 7, p. 294.

59. "Short Report on a closed members' meeting of the VSTP in the S1 school at Poengkoerweg, March 9, 1923," enclosed in Attorney-General to Governor-General, March 22, 1923, V 1 October 1923 - E14.

60. Speech at a VSTP meeting in Bandung on March 12, 1923, Matahari, April 17, 1923, IPO, Pt. 1, No. 17, pp. 176-78.

61. "Short Report on a closed members' meeting of the VSTP in the S1 school at Poengkoerweg, March 9, 1923," enclosed in Attorney-General to Governor-General, March 22, 1923, V 1 October 1923 - E14.

62. Attorney-General to Governor-General, March 2, 1923, V 1 October 1923 - E14. 
The Attorney-General continued to press his case throughout March, and forwarded more police reports purporting to show the subversive activities of the two communists. ${ }^{63}$ On April 16, Fock informed the Resident of Semarang of his decision against interning Semaun and Darsono for the time being, and instructed that, instead, he issue a strong warning to both men and keep them under closer surveillance. Fock wanted the warning issued immediately because the question of a strike would be discussed at the VSTP Congress due to be held on April 30. If stronger evidence emerged, then he might move to intern the two men. ${ }^{64}$

The Resident of Semarang, J. van Gigch, summoned Semaun and Darsono on April 18 and instructed them to moderate their activities or they would face internment. Neither was cowed by this warning, and Semaun spiritedly responded that, as he had no idea why he was being warned, there was no way in which he could guarantee to satisfy the government's wishes. Van Gigch replied that he too could guarantee nothing. Darsono was no more repentant, asserting "I only do what I consider my duty to myself and the people," to which the far-from-amused Resident responded that the government also only did what it considered its duty. ${ }^{65}$

The Resident's report might have been accepted without particular comment in Batavia, except that he sent with it a translation of a speech Semaun supposedly gave at a meeting of the Federation of Native Employees of Regional and Municipal Councils (Perserikatan Kaum Buruh Locale Ressorten Hindia) on April 1. Part of the account of Semaun's speech stated:

Our attitude, said the speaker, if a revolution does break out--I said if, not, come, let us make a rebellion tomorrow--is that we must urge our trade union not to kill any white people, but merely put them in jail, as hostages, so that the white people cannot use bombs against us. This way, we will ensure there is no destruction and no killing, but imprisonment only with an undertaking to send them all home. Further, 100 white people can be exchanged for 100 rifles, 10,000 white people for a warship.

In this way there will be no bloodshed and we will be able to be free. ${ }^{66}$

It is impossible to determine the accuracy of this report on Semaun's speech, as no source was given and it was not included in contemporary newspaper reports of the meeting. It presumably originated from a police agent present at the meeting. The accuracy of such reports had frequently in the past been questioned by Residents, Attorneys-General, and Governors-General alike. If Semaun did, in fact, say what he was reported to have said, it was certainly out of character for a man who, since his entry into the labor movement and nationalist politics in 1914, had been remarkably moderate in his public speeches and actions. Accurate or not, it was interpreted by the government as an incitement to violence and provided the public justification that Governor-General Fock needed to take the action he had rejected just over a month earlier. On May 8 Semaun was arrested.

Fock knew only too well that the arrest of Semaun would be the catalyst for a railway strike. In reporting to the Minister of Colonies, he cited as the three major considerations behind his action: the report of Semaun's April 1 speech; Semaun's

63. Attorney-General to Governor-General, March 22 and March 31, 1923.

64. General Secretary to Resident of Semarang, Very Secret letter N, April 16, 1922 , V 1 October 1923 - E14.

65. Resident of Semarang to Governor-General, April 20, 1923, V 1 October 1923 E14.

66. Enclosure in ibid. 
cavalier response to the warning from the Resident of Semarang; and the VSTP's Manifesto of April 23 which stated that a strike could break out any time. ${ }^{67}$ He also cited Semaun's defiant challenge on April 30 at a PVH meeting in Surabaya, which was repeated on May 6 at a VSTP meeting in Semarang, that, if he or any other VSTP leader was arrested, then the strike would break out immediately. No one of these factors was decisive but, collectively, they were more than enough to convince Fock that he had waited long enough. He may also have reasoned that, as he would have to take action sometime, it was better to do so before May 8, when the VSTP leaders began their propaganda tour. Fock had only become aware of the proposed tour on May 1, when the Resident of Semarang sent him a copy of the VSTP Manifesto of April 23. This could have convinced him that it was better to precipitate a strike immediately, before the VSTP was fully prepared, so that it could be smashed well before the peak of the sugar-milling season when the railways were vital for the transport of sugar from the inland mills to the ports.

Precipitating the strike had a further important advantage to the colonial government. It could now argue that the strike was directed against the government itself, rather than against the railway companies, thereby becoming a political action deliberately challenging law and order in the colony. If the strike had broken out in July or August the government would have had greater difficulty in ignoring its essential economic causes. At that time there was no legal prohibition against strikes in the colony and the government's oft-repeated position was that it did not necessarily oppose all industrial action taken to improve the conditions of workers. By striking immediately upon Semaun's arrest, the VSTP allowed the government to justify the repressive measures it adopted to break both the strike and the union. The Council of the Netherlands Indies, in later recommending the internment of Semaun and Darsono, summed up the attitudes of both the government and most of the European community when it argued:

A strike occurring as a reaction to the application of the general legal code undoubtedly has a revolutionary character. All leading figures in the VSTP are in equal measure guilty. None of them have spoken against the calling of a strike as a consequence of the arrest of Semaun. ${ }^{68}$

\section{Outbreak of the Strike}

The news of Semaun's arrest on the morning of May 8 was quickly conveyed to the VSTP offices from which handbills were soon distributed throughout Semarang, calling on railway workers to strike. Around noon, a VSTP leader went to the carpenters' workshop of the Semarang-Joana Steamtram Company and soon afterwards some 150 workers, about one-third of the workforce, laid down their tools and went home. ${ }^{69}$ The railway strike had begun.

The afternoon of May 8 must have been hectic in the Semarang headquarters of the VSTP, as union leaders planned their response to the government's action. They were joined during the afternoon by local PKI and Sarekat Islam leaders and by leaders of other unions in the city. Telephone calls were made to the Pawnshop Workers' Union headquarters in Yogyakarta and to Suroso, the chairman of the

67. Governor-General to Minister of Colonies, May 16, 1923, V 14 July 1923 - 15.

68. Advice of the Council of the Netherlands Indies, June 1, 1923 (No. XLV), V 1 October 1923 - E14.

69. Locomotief, May 8, 1923; Resident of Semarang to Governor-General, May 31, $1923, \mathrm{~V} 24$ August $1924-24$. 
Indies Trade Union Federation (PVH) in Mojokerto, seeking support. A decision was quickly reached to hold a meeting that evening: willing helpers went into the workplaces and kampung to spread handbills urging all railway and tramway workers to attend. Executive members, too, caught the first available trains out of Semarang to take circulars to other towns reminding members of the decision to strike the moment Semaun was arrested. ${ }^{70}$

The afternoon edition of Sinar Hindia carried a front-page report of Semaun's arrest which, to gain added sympathy, was juxtaposed with news of the birth of his son barely half an hour earlier. Not that this was needed, for the mood of railway workers had been evident for some months. After calling on all railway and tramway workers to strike, the editorial stated its belief that the strike would be greeted with joy by all workers and would be a significant page in the history of the Indies. It concluded by printing a series of exhortations urging preparedness, determination, and caution:

"When you strike it is not necessary for you to take up arms. Sleep only, and the employers' stomachs will become flatter."

"Hey proletarians! Join the ranks quickly. Away with the perfidious capitalists."

"Listen to no sweet words from the other side; it is all poison. Trust only your own power." 71

So many people attended the meeting that evening that the venue had to be moved from the VSTP offices to the much larger Sarekat Islam building across the road. The assistant police commissioner in Semarang was present, supported by a detachment of armed police lined up outside, rifles at the ready, in case of disturbances. ${ }^{72}$ Undeterred, the meeting unanimously decided to strike the following day and not to return to work until Semaun was released. Moreover, it called on the private railway companies and the State Railways to meet the demands adopted by the VSTP Congress on February 3: restoration of cost-of-living allowances; the establishment of an Arbitration Board; and the introduction of an eight-hour day . By general acclaim, Sugono was appointed "strike dictator," in place of the arrested Semaun, and head of the "Central Leadership of the Rail and Tram Strike in the Netherlands Indies." 73

On the morning of May 9 only one Indonesian worker, a ticket seller, turned up for work at the Semarang SCS Station at the normal starting time of 5:30 a.m. At the SJS Station a few station workers reported for work, but no engine-drivers, firemen, or shunters. In contrast, most workers at the NIS turned up as usual,

70. Locomotief, May 8, 1923; Resident of Semarang to Governor-General, May 31, 1923, V 24 August 1924 - 24. Many of these Executive members were arrested on May 9 and 10 as they made their way from branch to branch urging workers to join the strike. Sudibio, for example, first went to Pekalongan on the afternoon of May 8 but was arrested at Tegal early on May 10. Head of Operations SCM Tegal to Directors, May 16, 1923, Sister Societies Common Archives, 745-I.

71. Sinar Hindia, May 8, 1923, IPO, 1923, Pt. 1, No. 20, p. 298.

72. Locomotief, May 9, 1923.

73. These paragraphs are based on a detailed report on the strike in Semarang: prepared by its Resident, J. van Gigch. Resident of Semarang to Governor-General, May 31, 1923, V 24 August 1924 - 24. 
though the following day many joined the strike. ${ }^{74} \mathrm{~A}$ few early morning passenger trains into or out of Semarang were canceled, as were many goods trains that day, but most passenger services were maintained, albeit sometimes behind schedule. The companies coped by swinging into effect well-laid contingency plans. European supervisors and office workers were detailed to man the ticket counters, act as conductors and engine-drivers, and even to take on the arduous work of stokers. The Semarang city tram service operated by the SJS was maintained, not only by European staff labor but also by Indonesian students from the local technical school, who were released from school to work as stokers, bellmen, and conductors, jobs which they doubtless found far more exciting than the normal daily lessons. ${ }^{75}$

The VSTP Central Executive's Manifesto reached Surabaya sometime late on the afternoon of May 8, presumably carried by a courier on the afternoon train from Semarang. It was not until the following day that it was widely distributed, and news of Semaun's arrest filtered into the workplaces and stations. The lateness of its receipt prevented the Surabaya branch from organizing a public meeting until the evening of May 9, but as Surabaya had been one of the branches calling loudest for a strike, its decision was a foregone conclusion. On the morning of May 10, an estimated 90 percent of the Indonesian workforce failed to turn up for work at the Surabaya stations of the State Railways. ${ }^{76}$ A local reporter described the chaos at the city station which since seven that morning had been crowded not only with people wanting to travel but also with those curious to find out what was going on. The station was ringed by local town police and by troops, who barred all nontraveling Indonesians from entering, whether or not they held valid platform tickets. The other Surabaya station, at Gubeng, was also crowded, as trains were delayed or canceled. As each train pulled out of the Gubeng station, soldiers stood nearby, rifles at the ready, in case any strikers attempted to prevent its departure. ${ }^{77}$

\section{Locomotief, May 9, 1923.}

75. Involvement of pupils from the technical school became a heated topic of debate at a meeting of the Semarang Municipal Council on May 11, 1923. One Indonesian member, Sumali, drew the council's attention to the fact that pupils from the technical school were being employed by the SJS as strike-breakers. The chairman of the council was D. J. A. Westerveld, a long-standing member of the SDAP and a prominent voice for improvements in native housing in Semarang. He noted that the school received a subsidy from the municipality and also that there was an SJS representative on its board. He questioned what pressures the pupils were under to work as strike-breakers and sought council approval for his raising the matter with the director of the technical school. The council divided on the motion, thereby defeating it.

The following day the editor of Locomotief delivered a strong rebuke to Westerveld, reminding him that the first task of a mayor was to uphold authority: "One cannot speak of child labor here, for they are fine, strapping young men who stand on the engines of the town trams. Here is a spontaneously formed corps of young voluntary workers, who are not doing the work of sordid blacklegs, rather they are serving the community by helping to maintain a public service, which people have wilfully tried to dislocate." Locomotief, May 12,1923; Extract from Notes of a Meeting of Semarang Municipal Council, May 11, 1923, enclosed in Resident of Semarang to Governor-General, May 18, 1923, V 24 August $1924-24$.

76. Resident of Surabaya to Governor-General, May 10, 1923, V 17 December 1923 018.

77. Kemadioean Hindia, May 12, 1923. 
By May 9, the strike in the Sister Societies' network had spread from Semarang to Pekalongan, where only five people turned up for work at the SCS station. By May 10, it had extended to Tegal and Cirebon, as strike leaders went along the lines persuading workers to stop work, and on May 12 workers at the SCS workshops in Semarang also joined the strike. The day before, eleven of the workshop workers had signed a letter on behalf of themselves and their colleagues directed to the Head of Operations of the SCS at Semarang, threatening strike action if three specific demands were not immediately agreed to:

1. Wages to be restored to their level before April 1 when they were reduced by between 1 and 2 cents per hour.

2. Holiday allowances to be reintroduced.

3. Annual increases in wages to be introduced.

The eleven who signed the letter were some of the oldest and most skilled workers in the workshops and for this reason the Head of Operations summoned them to find out why they had made these demands. The men answered that the cost of house rents, food, and education for their children was so high that they could not live on the reduced wages. Their demands were rejected and they were warned that, if they went on strike, the SCS would immediately dismiss them and when the strike was over would not reemploy as many as it now did. When pressed, the eleven signatories are reported to have said that, although they personally did not want to strike, they were under considerable pressure from younger people in the workshop, especially from those who only earned between 10 and 12 cents an hour. Unmoved, the Head of Operations told them that those who wanted to continue working would be given police protection. ${ }^{78}$

At its peak on May 13, around 10,000 workers were on strike out of a total native workforce in all the railway and tramway companies in Java of about 50,000. The strike was concentrated in the State Railways, with 8,285 strikers out of a total native workforce of about 26,000. These strikers were almost entirely confined to the Central and East Java lines of the State Railways, and only a handful from West Java participated. Around 5,000 of the strikers were employed in Surabaya Residency, 1,700 in Madiun, over 600 in Kediri (all in East Java), and more than 700 in Yogyakarta, Central Java. ${ }^{79}$ The strike was almost total in Surabaya city, with about 90 percent of the native workforce of approximately 1,200 failing to show up for work on May 10, the first day of the strike. ${ }^{80}$ In Kediri, over 60 percent of the native workforce joined the strike. ${ }^{81}$ In Madiun, the 1,700 strikers, almost the entire workforce in the railway workshops and stations, were evenly distributed among skilled and unskilled workers. On May 11, 273 out of 314 tradesmen were on strike, 123 out of 134 apprentices, 28 out of 30 drivers, all 333 firemen,

78. "Resumé of a meeting between a deputation of personnel from the SCS workshop and the Head of Operations on May 12," enclosed in Head of Operations SCM Tegal to Directors, May 16, 1923, Sister Societies Common Archives, 745-I.

79. Resident of Surabaya to Governor-General, June 9, 1923, V 24 August $1924-24$; Resident of Madiun to Governor-General, August 18,1923, V 17 December 1923 - 018; Neratia, May 15, 1923.

80. Resident of Surabaya to Governor-General, May 10, 1923, V 17 December 1923 018.

81. Resident of Kediri to Governor-General, August 11, 1923, V 3 November 1923 E16. 
1,073 out of 1,221 workers in the workshops, 5 out of 8 warehouse keepers, and 188 out of 202 day laborers. ${ }^{82}$

The strike in the State Railways was concentrated in East and Central Java, largely because the VSTP was better organized in those regions and had since 1915 been able to focus workers' grievances there, while it had never succeeded in attracting more than a small proportion of railway workers in West Java. Moreover, despite the fact that State Railways wages and conditions were reasonably uniform throughout Java (though generally higher in the cities than at rural stations), workers came into contact with their higher-paid counterparts in the private companies only in East and Central Java. With the State Railways in a monopoly position in West Java, the workers were less likely to be aware of wage differentials between the State and private employees. Ordinary workers, then, were considerably more militant on the East and Central Java lines.

Many fewer workers went on strike in the two major private companies. In the Sister Societies over 1,300 workers participated, but in the NIS only 325 out of a total native workforce of about 9,000 joined the strike. Most of these were Semarang-based workers and more than a third of them returned to work within the seventy-two hour deadline set by the company. While NIS operations were little affected after May 9, the services of the Sister Societies and the State Railways in Central and East Java were much reduced for some weeks and the trains were very crowded, with goods and services not returning to normal until some time in June. ${ }^{83}$

\section{Breaking the Strike}

After the strikes in the SCS in August and October 1920, the strike waves in Semarang and Surabaya that year, and the strikes in the sugar industry between 1919 and 1921, the government in 1921 and 1922 had drawn up detailed plans, involving cooperation between Residents, local police commissioners, and army and navy commanders, in the event of future strikes. ${ }^{84}$ As the railway strike spread from Semarang, local Residents immediately put these contingency plans into effect. Armed police were sent to patrol the kampung, especially those where strikers lived, and, in conjunction with troops and marines rushed from local barracks, guarded railway stations, public buildings, bridges, gasworks, water works, and the railway lines themselves. Until July 1923, and as late as August in Surabaya, most of the major towns in Java resembled armed camps, as police, troops, and marines ostentatiously patrolled streets and lanes and guarded public buildings.

If this was not enough, on May 10 a further clause was added to the battery of colonial laws designed to maintain "tranquillity and order." The new article, 161 bis, which had been prepared much earlier, banned not only incitement to strike but

82. Resident of Madiun to Governor-General, May 15, 1923, V 3 November 1923 E16.

83. Governor-General to Minister of Colonies, May 26, 1924, V 4 August 1924 - L10; Head of Operations SCM Tegal to Chief Representative Sister Societies, June 20, 1923, Sister Societies Common Archives, 745-I; Chairman Executive Committee NIS to Chairman Board of Directors, Semarang, November 14, 1923, NIS Cabinet Archives, Nr 400; Resident of Semarang to Governor-General, May 31, 1923, V 24 March 1924 - 24.

84. A detailed file containing contingency plans for each Residency is in $\mathrm{V} 28$ December 1921 - B14. 
also support or encouragement to strikers. ${ }^{85}$ On May 12, temporary bans on public meetings were applied to the Residencies of Semarang, Kediri, Madiun, Pekalongan, and the Priangan, and on May 14 to Surabaya as well. ${ }^{86}$

In December 1922, when it appeared that local discontent might force a strike, the State Railways management had warned that workers who went on strike would be breaking their contract of employment and would be dismissed. On May 9, it began to carry out this threat. At the Sister Societies, as soon as the strike broke out, the Head of Operations ordered notices to be placed in all stations and workplaces informing employees that any person absent from work longer than twentyfour hours would be dismissed. The NIS followed suit, though perhaps because it was less affected and believed that many of its workers were striking in sympathy rather than from deep-seated grievances against the company, it allowed them three days to return to work without penalty, after which they would be dismissed. On May 10, the government's proclamation of Article 161 bis was posted in all stations in the Sister Societies' network as a warning to potential strikers. The new law was swiftly applied. On the morning of May 11, for example, a haltechef who went on strike was arrested by the wedana of Adiwerna for transgressing Article 161 bis and Article 194 of the Penal Code. ${ }^{87}$ To impress others with the consequences of their actions, the Head of Operations of the SCS at Tegal sent telegrams to all haltechefs and stationchefs informing them that, if they left their posts, they would be in breach of articles 161 bis and 194. The Head of Operations commented to his superiors: "I firmly believe that these arrests have made an impression on the workers." 88

If the new penal laws and the sackings were intended to intimidate workers and prevent the strike spreading, so too was the ostentatious use of armed police, troops, and marines in towns and cities. Armed police and troops patrolled the railway workers' kampung, and those prepared to work were shepherded to and from work by them. In Surabaya, for example, city police worked long shifts, rural police were used to guard railway and tram lines, and troops were brought in: more than 120 troops from the Mangkunegaran Legion in Surakarta, 100 from Madura, three companies from Malang, and a small force of 45 marines from the Surabaya naval base. ${ }^{89}$ In Bandung, even though only a handful of railway workers joined the strike, the Resident took no chances, organizing extra police patrols through kampung where State Railways employees lived. Some workers were reported to be so frightened of being arrested that they slept the night at the stations rather than risk being picked up by a patrol on their way home. ${ }^{90}$

The government marshaled its provincial administration in the effort to prevent railway workers joining the strike. On the night of May 10, for example, the Assistant Resident of Solo, his police commissioner, and the local patih and wedana,

85. Locomotief, May 10, 1923.

86. Governor-General to Minister of Colonies, May 16, 1923, V 14 July 1923-15.

87. Kemadjoean Hindia, May 11, 1923.

88. Head of Operations SCM Tegal to Directors, May 16, 1923, Sister Societies Common Archives, 745-I.

89. Patrol work in the kampung of Surabaya, which involved squelching through the muddy paths that served as roads and enduring a mosquito plague, was not to the liking of the troops, as their commander complained to the Resident of Surabaya. Resident of Surabaya to Governor-General, June 2, 1923, V 24 August $1924-24$.

90. Locomotief, May 14, 1923. 
went from house to house informing railway workers of the new antistrike laws and warning them of the consequences of striking. Earlier that day a group of Semarang workers, who had traveled to Solo to persuade workers there to strike, were arrested. ${ }^{11}$ The efforts of traditional authority figures were, however, not always successful. At Sidotopo, for example, when the regent and patih, together with the chief commissioner of police, met striking workers to try to persuade them to return to work, the workers refused unless Semaun was first released from jail. ${ }^{92}$ At a VSTP meeting at Pekalongan on May 9, the chairman of the meeting forbade the local patih from speaking, when he tried to persuade those present to change their minds and return to work. ${ }^{93}$ The changes in the urban work force's attitudes to authority meant that, by the $1920 \mathrm{~s}$, in the towns and cities traditional indigenous authority figures no longer possessed their earlier powers of patronage and could no longer rely on the politics of deference to maintain social control.

On May 13, the State Railways increased their pressure by ordering all strikers who lived in railway houses to vacate them within forty-eight hours, as they were no longer employed by the railways. Armed police efficiently carried out evictions in Surabaya, Semarang, Madiun, Cirebon, and wherever else the State Railways rented out houses to its workers. In Surabaya, for example, where 880 State Railways-owned houses were rented out to Indonesian workers, only eighty-one were still occupied by May 18. All the rest had been vacated by strikers and their families or by employees who were still at work but were frightened of retaliation if they stayed in the railway kampung. ${ }^{94}$ Most of the occupants had left before the May 15 deadline, but 270 houses, homes to an estimated 2,000 workers and their families, were forcibly emptied late in the afternoon of May 15. The Resident of Surabaya was worried not only that the expulsions might be resisted but, even if they were carried out peaceably, that so many homeless people would be a danger to public order in Surabaya. At his own request, he had toured the State Railways kampung on May 13 accompanied by a contingent of police, urging workers to leave voluntarily, and he set aside an old customs house for their overnight use. ${ }^{95}$ His concern was unfounded, for the ejection of the 270 families took place calmly. ${ }^{96}$ D. M. G. Koch, the editor of the East Java edition of the Indische Courant and generally sympathetic to the strikers' cause, graphically recalled the scene that day in one of the kampung:

There was in Surabaya a neighborhood of about three hundred company houses for lower personnel of the state rail line. On the morning the strike began the people received orders to move out of those houses; police and soldiers dragged furniture and household goods from them. It was a miserable sight. Weeping women sat with their few possessions on the roadside, in a drizzling rain. 97

The evicted families spurned the Resident's offer of the customs house, preferring to move in with friends or with families who responded to calls made by the

91. Ibid., May 11, 1923.

92. Kemadjoean Hindia, May 11, 1923.

93. Locomotief, May 11, 1923.

94. Resident of Surabaya to Governor-General, May 18, 1923, V 24 August $1924-24$.

95. Kemadjoean Hindia, May 14, 1923.

96. Resident of Surabaya to Governor-General, May 13, 1923 and May 18, 1923, V 24 August 1924 - 24; Locomotief, May 16, 1923.

97. Quoted in McVey, Rise of Indonesian Communism, p. 151. 
Surabaya branches of the VSTP and Sarekat Islam. ${ }^{98}$ This scene was repeated elsewhere, with no resistance offered by the evicted workers.

The VSTP Central Executive had certainly been forced to proclaim the strike before it was properly prepared. Nevertheless, given its constant difficulties of communication with branch executives and the loose structure of all unions in colonial Java, where so much initiative lay with local leaders, it is difficult to see how it could have been better prepared, even if the strike had occurred later, at a date of its own choosing. As soon as the strike was announced, the Executive despatched leaders to the major branches and throughout the railway networks to embolden and at the same time supervise local leaders. This strategy halted abruptly with the proclamation of Article 161 bis on May 10, when local Residents picked the leaders up one by one as they entered their territories, placing them in "preventive detention" charged with breaking the new law. Local leaders suffered the same fate. By May 15, twenty-two people, nearly all of them VSTP central or branch executive members, had been arrested and jailed under the new law. ${ }^{99}$ No official figures have been found for the number of people arrested during the course of the strike. under Article 161 bis, but contemporary accounts estimate the total at between 120 and 140 , including fifty-seven VSTP leaders. ${ }^{100}$ All of them were subsequently jailed for periods extending from a few days to a few months.

Equally important in destroying the VSTP leaders' ability to direct and control the strike were the bans on the holding of public meetings,imposed on May 12 and 14 . Under these bans even closed members' meetings needed government approval, and this had to be sought five days in advance. The VSTP was forbidden from holding any kind of meeting and, as the strike progressed, the restrictions were increasingly applied to other unions considered sympathetic. In addition, the Resident of Semarang isolated VSTP headquarters from the rest of the union. Armed police guarded the office, with VSTP members only permitted entry if they showed their membership cards, and, even then, only two at a time. Police guards were also placed outside the Semarang homes of Central Executive members, with VSTP members again permitted to enter only two at a time. ${ }^{101}$ In an open letter published in the PKI newspaper Sinar Hindia on May 16, Sugono, the strike "dictator," lashed out at the government's description of the strike as a political action, which it had used to justify the extreme measures taken against the strikers. ${ }^{102}$ He reiterated that the VSTP had tried over many months to negotiate a settlement of workers'

98. Locomotief, May 16, 1923; Kemadjoean Hindia, May 16, 1923.

99. Locomotief, May 16, 1923. The two European members of the VSTP Central Executive, Zeijdel and Sersanzie, resigned a few days after the outbreak of the strike, after being told by the chairman of the management committee of NIS that they had to choose between resigning from the VSTP or losing their jobs. Resident of Semarang to Governor-General, May 31, 1923, V 24 August $1924-24$.

100. Cited in McVey, Rise of Indonesian Communism, p. 416 n. 134.

101. Sinar Hindia, May 24, 1923, IPO, 1923, Pt. 2, No. 22, p. 383; "Letter addressed to the inhabitants of the Indies by Soegono, VSTP, May 16, 1923," Sinar Hindia, May 16, 1923, reprinted in P.E.B., June 21, 1923, copy in Sister Societies Common Archives, 745-I. Soetadi, a prominent Indonesian member of the Volksraad, quoting from Sinar Hindia, said that "Semaun's wife was also allowed women visitors but also only two at a time." Handelingen der Volksraad, June 13, 1923, p. 80.

102. "Letter addressed to the inhabitants of the Indies by Soegono, VSTP, May 16, 1923," Sinar Hindia, May 16, 1923, reprinted in P.E.B., June 21, 1923, copy in Sister Societies Common Archives, 745-I. 
grievances with railway managements, but to no avail; and it had used every means in its power to calm down the anger of members. Despite all this, he argued:

The sana party has never understood that the leaders can do nothing if it is not the wish of their people.

Although clever, the sana party has still never understood that the leaders work for their people and not for themselves.

The sana party has never understood, nor will understand, that the present economy measures have led to general discontent. ${ }^{103}$

Not only were restrictions placed on VSTP public and private meetings, its leaders arrested, and its members dismissed, but, continued Sugono, the telephone at VSTP headquarters was disconnected and all union mail impounded, with the result that the Central Executive had completely lost contact with the branches. As the VSTP leaders no longer had control of the strike, Sugono asserted, they were absolved of responsibility for anything that now happened.

\section{Supporters, Sabotage, and Violence}

The government's unprecedented precautions were in anticipation of sabotage of trains and equipment and violence in the kampung and town centers. Despite the emotional atmosphere, where low-paid workers had to feed themselves and their families without savings on which to fall back, while many were evicted from their homes, remarkably little sabotage took place. There were a few reported cases of points being put out of action, telegraph wires cut, an attempted fire in a timber yard, or an attempt to cut off the water supply to a workshop, but nothing of any significance. Similarly, there was little violence beyond occasional reports of stones being thrown at houses of people still at work, anonymous threatening letters sent to station-masters, or threats and intimidation of those who did not strike. The strikers, of course, applied considerable pressure on their fellow workers to join them, and sometimes this was accompanied by threats. But government officials, railway managements, and European newspaper editors had little basis for asserting that intimidation was the major reason the strike lasted as long as it did, thereby ignoring its social and economic causes. ${ }^{204}$

Only two instances of crowd unrest were reported. On the evening of May 11 , 4,000 people turned up for a VSTP meeting in the Sarekat Islam building in Surabaya. Only a small part of the crowd could fit into the meeting, with the rest having to stand outside in the street where they blocked the road. When the police tried to clear the street, they were met by much jeering and some throwing of stones and fireworks. The police then drew their batons and forcibly dispersed the crowd. ${ }^{105}$ On another occasion, when a native policeman went into a State

103. Ibid. Sana literally means "there," and is here used to signify "the colonialists."

104. In fact, VSTP leaders complained of violence and intimidation being used by the police and the railway companies to force strikers back to work. See Sinar Hindia, May 22, 1923, IPO, 1923, Pt. 1, No. 22, pp. 380-81.

105. Locomotief, May 12, 1923; Sinar Hindia, May 12, 1923, IPO, 1923, Pt. 1, No. 20 , pp. 300-301. VSTP leaders responded by dividing the meeting into three sections so that all the people outside the building, who had been forced to disperse by the police, were able to attend later. 
Railways kampung in Surabaya on May 12 to arrest VSTP leader Sukartono, who was charged with inciting people to strike at a meeting the previous night, about 500 people gathered around the policeman threatening that unless Sukartono was released by mid-afternoon they would march on the police headquarters and free him themselves. The situation was defused by a passing military patrol, which moved in and dispersed the crowd, enabling the policeman to carry out his arrest. The crowd's anger was probably aroused by Sukartono's innocence of the charge, a fact acknowledged by the Assistant Resident who ordered his release later that afternoon. Nevertheless, as a result of this incident the Resident of Surabaya despatched a company of marines from the naval base to cut off and guard the State Railways kampung. ${ }^{106}$

Peer-group pressure, threats of violence, and, more importantly, fear of retribution after the strike was over, no doubt did play a part in persuading some workers to join the strike. But most, like the eleven older skilled workers in the SCS workshop at Semarang already referred to, were motivated by the cuts in wages, at a time when rents, food, and clothing prices were still reflecting the high inflation since 1913. ${ }^{107}$ When the strike broke out in Blitar, East Java, on May 11, the supervisor of town police went around strikers' houses asking each man why he had gone on strike. Of those at home, the engine-drivers, conductors, and other skilled workers for the most part replied that they were on strike because Semaun was in jail. Others said that they wanted a wage raise. Of lower-level workers, such as firemen, brakemen and pointsmen, most said that they went on strike out of solidarity with their workmates and some said that they feared retribution if they did not join the strike. ${ }^{108}$ The Resident of Banyumas, unable to accept economic grievances as the real reason for the strike, resorted to arguing that the strike had broken out at Maos in his Residency "because this is a locomotive depot, which has a high percentage of engine-drivers and train personnel, who are amongst the most recalcitrant of the workers." 109

When the strike began on May 8, the VSTP leaders had every reason to believe that they would be supported by other unions and by the nationalist movement. In this they were disappointed. Certainly, almost all union and nationalist leaders gave them moral support, despite the personal and ideological animosities between Semaun and other communist leaders of the VSTP and such prominent Sarekat Islam leaders as Tjokroaminoto and Surjopranoto of the Sugar Factory Employees' Union. But in the face of the government's relentless application of laws which even prevented money being collected for strikers' families, only limited concrete support was forthcoming. There were some sympathy strikes in Semarang, but they were restricted to a one-day strike by taxi drivers on May 10 and one by meat traders in local markets for two days. Typographers in the city also struck on May 14, partly in sympathy with the railway workers but essentially over a dispute about the payment of advance wages for the approaching Lebaran celebrations at the end of the Islamic fasting month. ${ }^{110}$ Sporadic brief sympathy strikes were also reported from Salatiga and Bandung. Other unions called on their members to sup-

106. Resident of Surabaya to Governor-General, May 13, 1923, V 24 August $1924-24$. 107. See above p. 58 .

108. Resident of Kediri to Governor-General, August 11, 1923, V 3 November 1923 E16.

109. Resident of Banyumas to Governor-General, May 15, 1923, V 44 August $1924-24$. 110. Locomotief, May 11 and 12, 1923; Resident of Semarang to Governor-General, May 31, 1923, V 24 August $1924-24$. 
port the striking railway workers, but once collecting money for them was prohibited there was little the other unions could do.

Nevertheless, some money was raised, after the VSTP ingeniously discovered that, once the railway companies had officially dismissed the strikers, the law prohibiting their support was no longer in effect. Support committees were set up in most of the larger railway towns, and money was raised by contribution cards being sent around the kampung and by the Sarekat Islam and the PKI making collections among their members. ${ }^{111}$ The VSTP's own strike fund was limited: in March 1923 it held only $\mathrm{f} 15,000$, or less than $\mathrm{f} 2$ per striker. 112 On May 30, the union resorted to raising a mortgage of $\mathrm{f} 10,000$ on its Semarang building from an unnamed Chinese source. ${ }^{113}$ Some additional help came from sympathetic European socialists, with D. M. G. Koch organizing collections of goods and money, and from individuals such as Tan Ping Tjiat, the wealthy Administrator of the East Java edition of Sin $P o$, one of the colony's leading Malay-language Chinese newspapers, who supplied rice to Surabaya strikers with payment to be made after the strike was over. 144 Another Chinese merchant at Sidotopo supplied two kati of rice per person per day to strikers, on condition that they would pay for it at current prices if and when they returned to work; otherwise no payment was required. 115

As soon as a worker joined the strike, credit from local stallholders and shopkeepers dried up, as in previous strikes, and European employers recognized that this would pressure strikers to return to work. A high proportion of railway workers' wives probably had some income, though insufficient to maintain a family. Once a family had pawned as many domestic items as it could dispense with, then the financial pressures to return to work increased. Some strikers found other jobs, on a temporary or a permanent basis, and some who were recent migrants to the city accepted sufficient money from strike support committees to return with their families to their home villages. Most, however, survived as best they could, with

111. A Comite Kemanusiaan [Humanitarian Committee] had been in existence in Surabaya since November 1920 . Its aim was to collect money and give assistance to wives and families of people in need, especially those on strike or dismissed from work. It was founded during a strike in the Surabaya Dry Dock Company and during the Pawnshop Workers' strike in 1922 supported strikers and their families. It was particularly active during the railway strike, using various methods to raise money and rice, including printing and distributing donation cards for circulation in the kampung, arranging for other voluntary bodies, such as football clubs and cultural associations, to raise money through special performances, and soliciting gifts from wealthier members of the Surabaya community. Some idea of the extent of its operations can be seen from the fact that in a three-week period between June 10 and July 2, 1923 it raised f436.23, comprising donations from the Sarekat Postel Committee in Surabaya, proceeds of a public meeting of the Surabaya branch of Sarekat Islam and donations from football clubs. In the same period it paid out f383.85, mainly in small amounts of $\mathrm{f} 5$, $\mathrm{f} 10$, or $\mathrm{f} 20$, but including sums of money sufficient to send striking railway workers or their families back to their home villages. See Kemadjoean Hindia, June 11, 1923.

112. Assistant Resident of Semarang to Resident of Semarang, June 1, 1923, V 24 August $1924-24$.

113. Ibid.

114. Resident of Surabaya to Governor-General, June 16, 1923, V 24 August $1924-24$.

115. Sinar Hindia, May 20, 1923, IPO, 1923, Pt. 1, No. 24, p. 475. 
support from family and friends, a little income from whatever work they could find, and some assistance from support committees.

The strike had broken out just a week before Lebaran, which severely disrupted the usual journeys of many urban workers from the towns and cities back to their villages of origin. VSTP leaders called on urban workers not to spend as much as usual on Lebaran festivities, but instead to give the money saved to the victims of the government's repression. ${ }^{116}$ One woman speaker at a public meeting on May 11 in Surabaya called on strikers to take heart because the strike had occurred in the puasa (fasting) month. The puasa, she said, was a time when the prophet Mohammad was struggling with those who offended Islam or were evil, and to celebrate his victory a feast was held at the end of the month. The strike, she continued, was similar, in that it was a struggle between workers and capitalists: after the workers' victory, they too could have a feast in celebration, but not before the victory was won. 113

The optimism of the early days of the strike, however, soon dissipated. Most strikers, along with many of their leaders, had expected railway managements to concede their demands very speedily. Few anticipated that the government would side with the employers to the extent that it did. Brave words aside, most were in no position to last more than a few days, or a week or two at the very most. ${ }^{118}$

\section{The End of the Strike}

On May 22, the VSTP Daily Executive called off the strike. With hundreds of strikers having returned to work and thousands more dismissed and replaced by new workers, the Executive was bowing to the inevitable. The Bulletin announcing its decision admitted that the strike had occurred unexpectedly and that the leaders had not anticipated the government's reaction. Strikers were assured that efforts were being made to gain their reemployment, but, it was admitted, so far without success. The Bulletin ended on a note not only of defeat but also of sadness:

Finally, the Daily Executive reports to its brother workers, that the strike would not have been launched in this way, and certainly would have been won, if the Companies on the one hand and the rail and tramway workers on the other hand were free to organize their actions. We are able to accomplish nothing more because we are bound hand and foot. We may not

116. Resident of Semarang to Governor-General, May 31, 1923, V 24 August $1924-24$; Sinar Hindia, May 12, 1923, IPO, 1923, Pt. 1, No. 20, pp. 300-302.

117. Sinar Hindia, May 12, 1923, IPO, 1923, Pt. 1, No. 20, pp. 300-302.

118. Writing in exile in Holland for The Netherlands Communist Party newspaper De Tribune, Tan Malaka was critical of Semaun in September 1922 for being too cautious in his unwillingmess to support an immediate railway strike. Malaka argued that "In the Indies if the discontent rises sharply then people can always strike. The absence of a winter, the small needs and the hospitality of the people are guarantees that the struggle can be sustained for many months if necessary." Quoted in Harry A. Poeze, Tan Malaka: Strijder voor Indonesië's Vrijheid. Levensloop van 1897 tot 1945 (The Hague: Nijhoff, 1976), p. 216. Dutch colonial officials often used a similar argument to stress the dangers of allowing union leaders to organize strikes. Semaun had argued in a similar vein in an interview published in Locomotief, September 29, 1921, though he generally made a more careful assessment of the need for a strike fund in the event of a lengthy strike. 
speak, we go hungry, and we no longer have any sympathy from our brothers. ${ }^{119}$

In the face of coordinated repression from government and railway managements, the isolated VSTP leadership could not bring the transport system to a standstill. It therefore had no bargaining power. Not only did European supervisory staff take over many of the skilled native workers' jobs, but also the tactics of the managements, and their threat of immediate dismissals, quickly broke the will of many strikers. Understandably, this was too high a price to pay and a significant number returned to work within the forty-eight or seventy-two hour deadlines laid down by the Sister Societies and the NIS respectively. In a society where thousands of people in the kampung were eager for work at any price, the railway managements had no difficulty recruiting unskilled labor or such semiskilled workers as pointsmen or stokers. The State Railways and the Sister Societies almost immediately advertised for people to train as conductors, and they had no trouble filling the courses. Skilled workers, such as engine-drivers, were harder to replace, but by using Europeans and promoting firemen the companies maintained their services.

When the strike broke out, the Sister Societies had posted notices in all stations and workplaces informing workers that, if they stayed away from work for more than one day, they would be dismissed and only reemployed at the Company's discretion on new wages and conditions. The company was determined not to reemploy those whom it believed to be the ringleaders of the strike, which included any VSTP branch executive members. They reemployed skilled workers whom they would have had some difficulty replacing, such as engine-drivers, firemen, shunters, and conductors, but ruthlessly refused to reemploy such semiskilled workers as brakemen, pointsmen, station hands, and even station clerks, whom they could replace with ease. ${ }^{120}$

Detailed statistical breakdowns of the strike in the SCS allows a closer analysis of the Sister Societies' largest operating company. A total of 779 workers went on strike, of whom twenty-six returned within the stipulated twenty-four hours, the remainder being dismissed. Of the 753 dismissed only 333 were later reemployed, of whom 183 were taken back as casual workers at wages 10 percent lower than those received before the strike, and 150 were taken back at a rate 15 percent lower. ${ }^{121}$ Enough workers drifted back by May 13 at Cirebon and Tegal to enable most passenger services to operate as normal, but full goods services could not be restored until the beginning of June. The Pekalongan strikers held out for another week, but the Semarang workers, who had begun the strike, were the last to admit defeat, with only one engine-driver and one fireman returning to work before the VSTP leaders called off the strike on May 22. The following day another nine drivers, nine firemen, and eight station workers returned. 122

119. "Bulletin of the Daily Executive of the Central Leadership of the Rail and Tramway Strike," enclosed in Resident of Semarang to Governor-General, June 8, 1923, V 24 August 1924-24. For reports on meetings between members of the VSTP Central Executive with the private railway and tramway companies on May 22 and 23, see Locomotief, May 22 and 23, 1923.

120. Head of Operations SCM Tegal to Directors, May 16, 1923, Sister Societies Common Archives, 745-I.

121. Head of Operations SCM Tegal to Chief Representative Sister Societies, June 20, 1923, Sister Societies Common Archives, 745-I.

122. Head of Operations SCM Tegal to Directors, May 23, 1923, Sister Societies Common Archives, 745-1. 
The SCS management was concerned at the refusal of so many skilled workers to return on the company's terms. On May 23, the Semarang station had only ten engine-drivers out of twenty-nine employed before the strike, ten firemen out of thirty-one, and twenty-seven line personnel out of fifty-one. The Pekalongan station had only eighteen engine-drivers out of twenty-two employed before the strike, nine firemen out of thirty-one, but all its line personnel. The Cirebon station had thirty engine-drivers out of thirty-eight employed before the strike, twenty-five firemen out of twenty-seven, and twenty line personnel out of fortyone. The refusal of conductors to return was even more marked: at Cirebon five out of twenty-two returned; at Tegal ten out of twenty-four; at Pekalongan seven out of eighteen, and at Semarang only one out of twenty-three. ${ }^{123}$

It seems clear that in the SCS the decision as to whether the workers went on strike at a particular station or halt, each of which employed between fifteen and forty men, greatly depended first on whether the station- or halt-master was a member of the VSTP and second on whether he favored the strike. From May 8 until May 10 or 11, when they were arrested under the new laws, VSTP leaders toured the lines trying to persuade station-masters and halt-masters to join the strike, while managements countered by threatening them with prosecution if they left their posts. Analyzing the strike for his directors in The Netherlands, the Head of Operations argued that, where natives in responsible positions, such as station- or halt-masters, were of priyayi origin, they did not go on strike and were a restraining influence on ordinary workers. He reasoned that in future the company should look to the social origins of natives before making the se key appointments. ${ }^{124}$ No additional evidence has been found to support this assessment, but an advertisement in Sinar Hindia after the strike was called off suggests that railway workers' social origins may have played some part in determining attitudes to the strike. The advertisement sarcastically asked:

Wanted

by the editor of Sinar Hindia people of the "fine" class, priyayi or Javanese satriya, competent in

a. flattery

b. selfish politics

c. corruption

Information to be sent to: Samsi

Chief Editor ${ }^{125}$

The class antagonism may have been aimed in large part at regents, patih, and other government officials, but was also probably aimed at the Indonesian administrative workers, station-masters, and. supervisory personnel among the 40,000 railway workers who did not join the strike.

Older, skilled workers seem to have been more reluctant to strike, not only in the Sister Societies but also in the State Railways. This reluctance stemmed partly from the conservatism of older workers in any society, concerned for their families and about the difficulty of getting another job, and also from their anxiety to protect their service increments and pension rights, the latter being their only security in old age. However, many did go on strike, perhaps because they shared the

123. Head of Operations SCM Tegal to Directors, May 23 and June 20, 1923, Sister Societies Common Archives, 745-I.

124. Head of Operations SCM Tegal to Directors, May 23, 1923, Sister Societies Common Archives, 745-I.

125. Sinar Hindia, May 22, 1923, IPO, 1923, Pt. 1, No. 22, p. 381. 
discontent of all railway workers and perhaps also because of pressure brought to bear on them by the younger, more impatient, workers. ${ }^{126}$ Some paid a heavy price. The SJS did not reemploy twenty-nine skilled workers with fifteen or more years service, and the SCS did not reemploy seventeen similar workers, all of whom were eventually granted considerably smaller pensions than they would otherwise have received. ${ }^{123}$

The Sister Societies made considerable financial savings as a result of the strike. They were overmanned at a time of recession and after the strike were able to employ fewer workers than they had before. They also reemployed strikers at 10 percent lower wages if they returned before May 15, or 15 percent lower if they returned after that date. No strikers were reemployed after May 29, 1923. ${ }^{128} \mathrm{Fi}-$ nally, as strikers were not paid any allowances, they were denied a productivity bonus for 1923 and lost their holiday entitlements, and those dismissed lost all or a major part of their pension entitlements. Reemployed strikers were not restored to permanent status until between January and July 1924, depending on the date of their return to work, and did not have their previous years of service counted towards salary increments or pensions until they had worked another five years. The SJS calculated that the loss of wages for the strikers it eventually reemployed would be $\mathrm{f} 25,277.10$ in 1923 alone, while the savings to the company on nonpayment of productivity bonuses would be another f11, 404.20. ${ }^{129}$

Of the 8,265 who went on strike in the State Railways, only 1,596 were reemployed. It was not simply that the State Railways did not wish to reemploy strikers. In fact, it tried to reemploy many more, but could not attract strikers back to work on even worse conditions than those that had caused the strike in the first place. It found particular difficulty in attracting back conductors, engine-drivers, and firemen. Of the 496 engine-drivers and 750 firemen who went on strike, only 138 and 143 respectively sought reemployment. ${ }^{130}$ Resentment at the low wages paid by the State Railways compared to either the private railway companies or other industries was strong enough for many strikers to refuse reemployment, even when it was offered. At the end of August, for example, 552 State Railways strikers at Madiun sought a meeting with the Resident. The Resident later reported that the strikers' spokesman, an ex-draughtsman named Djojodihardjo, took an "improper attitude," demanding to know "what the government had decided in relation to the strikers." The Resident reprimanded him and told the assembled strikers that he was only prepared to listen to them if they asked forgiveness for their actions.

126. See Head of Operations SCM Tegal to Directors, May 16, 1923, Sister Societies Common Archives, 745-I.

127. Chief Representative to Directors, December 5, 1923, Sister Societies Common Archives, 745-II.

128. Head of Operations SCM Tegal to Directors, May 29, 1923, Sister Societies Common Archives, 745-I.

129. Chief Representative to Directors, November 30,1923, Sister Societies Common Archives, 745-II. As an "act of generosity" the SJS paid 50 percent of its normal productivity bonus for 1923. Even more generously, the chief representative of the Sister Societies in June decided against withdrawing the strikers' bonus for 1922 , which had still not been paid when the strike broke out. Chief Representative to Directors, June 4, 1923, Sister Societies Common Archives, 745-I.

130. "Memorandum by Chief Representative, Sister Societies, July 7, 1923," enclosed in Chief Representative to Directors, July 12, 1923, Sister Societies Common Archives, 745-I. 
Other strikers asked the Regent and the Resident to mediate on their behalf with the State Railways, but the State Railways Inspector present stated sharply that they would only be taken back on the new wages and conditions. The following morning only 167 out of the 522 who had attended the meeting sought reemployment. 131

What happened to the thousands of strikers either refused or not seeking reemployment? The Resident of Surabaya reported in July that of the 920 strikers not reemployed in that city only 120 had returned to their villages, and of the 800 remaining about 500 were still without work two months after the strike had begun. ${ }^{132}$ Some, however, had managed to find work as washmen, houseboys, mechanics, or drivers. On August 15, he reported that only 147 of the original strikers were still without work. ${ }^{133}$ Alternative work was much harder to find in Madiun, where in the middle of August the Resident estimated that there were still 1,153 strikers refusing to return to work or being refused reemployment, the majority of whom were unemployed. ${ }^{134}$ Further, union as well as government reports indicate that hundreds of dismissed strikers still had no permanent work more than a year later. Presumably, those who did not return to their villages of origin simply joined the thousands of others in kampung of the major cities who eked out a living as casual day laborers.

The high proportion of skilled workers not seeking reemployment is more difficult to explain. All the railway networks suffered a severe shortage of drivers and firemen for many months after the strike was over. Some engine-drivers may have been able to get jobs with the sugar mills, where there was generally a shortage of such workers. The sugar mills were not averse to employing former strikers, and even during the strikes in the sugar industry between 1919 and 1921 many had quietly employed strikers from rival mills. Other engine-drivers may have found work in the metal industries in Surabaya, where their familiarity with operating modern machinery would be valued. Wages for engine-drivers in the sugar mills and for skilled metal workers in Surabaya were generally higher than in the railway industry. Many engine-drivers who obtained work with a sugar mill may have taken their stokers with them, but alternative work for other stokers would not have been easy to obtain. Conductors also would have found difficulty in obtaining alternative employment because of the specialized nature of their work. The refusal of so many of them to seek reemployment puzzled railway managements at the time, with available reports indicating that they seem to have gone to a variety of other jobs in the cities, ranging from houseboys to chauffeurs. ${ }^{135}$ The skilled workers, especially engine-drivers, conductors, and station-masters, had been in the forefront of VSTP activities over many years, holding most of the branch executive positions and being the staunchest advocates of strike action. A high proportion of them were at least functionally literate and appear to have developed a greater sense of

131. Resident of Madiun to Governor-General, September 5, 1923, V 17 December 1923 - 018.

132. Resident of Surabaya to Governor-General, July 14, 1923, V 3 November 1923 - E16.

133. Resident of Surabaya to Governor-General, August 15, 1923, V 17 December 1923 - O18.

134. Resident of Madiun to Governor-General, August 18, 1923, V 17 December 1923 - O18.

135. Resident of Surabaya to Governor-General, June 23, 1923, V 24 August 1924 - 24 . 
the injustice of their situation than the less skilled workers. Rather than accept defeat and even worse conditions of employment, many seem to have decided to move out of the railway industry altogether. It seems that a high proportion of these were younger men, more mobile and less immediately concerned about pension rights.

\section{Conclusion}

The strike was swiftly and ruthlessly crushed and the VSTP with it. Semaun personally paid a heavy price. He was exiled in August 1923, not to return to his homeland until 1957. The VSTP lost not only its chairman but also many of its central and local leaders, who were either jailed or dismissed from their jobs. Thousands of ordinary members reacted to the inability of their union to protect them from either employers or government by letting their membership lapse. The VSTP went into the strike with about 13,000 members but when it was all over only 535 remained. Despite considerable rebuilding in 1924 and 1925 , when it reached a new peak in November 1925 with seventy-seven branches and 8,292 members, the VSTP was unable to regain its earlier momentum. ${ }^{136}$ Along with other communist-led labor unions, it was again heavily restricted in 1926 , a restriction which turned into an outright ban after the destruction of the PKI at the end of that year.

Samsi, the chief editor of the PKI newspaper Sinar Hindia at the time of the strike, compared the government's suppression of worker discontent with efforts to check the course of a river by building a dam. If the water becomes high enough then the dam will be destroyed by its power. ${ }^{137}$ In a later article he cautioned capitalists in the colony against seizing the opportunity to suppress their workers even further, for by so doing, he argued, they would only be digging their own graves. ${ }^{138}$ In his written self-defense prior to being exiled, Semaun too warned the government that the workers' discontent could not be suppressed forever. ${ }^{139}$ Neither government nor managements were moved by the warnings, confident that they had won an important victory.

Indeed, the failure of the strike did demonstrate the weakness of labor unions in colonial Indonesia in the face of coordinated government and industry action. Dutch commercial and industrial interests in Indonesia were determined to maintain a cheap labor supply and had begun to organize themselves to counter the native labor unions. The government, for its part, had increasingly hardened its attitude towards the labor unions since 1921 . The 1923 railway strike was the first major test of its new tough policy. After the railway strike was over the antistrike sections added to the Penal Code in May 1923 remained as a potent weapon for future use. Henceforth, organized strikes were to be treated as challenges to colonial authority. Irrespective of the political affiliation of its leaders, it would in future be extremely difficult for any union to force improvements in wages and conditions.

136. Si Tetap, February-March 1926.

137. Sinar Hindia, May 19, 1923, IPO, 1923, Pt. 1, No. 21, pp. 350-51.

138. Sinar Hindia, June $3,1923, I P O, 1923$, Pt. 1, No. 24, p. 478.

139. "Memorie van verdediging van Semaun," July 19, 1923 [Statement of Defense by Semaun], V 1 October 1923 - E 14 . 